Santa Clara University

Scholar Commons

Civil Engineering

School of Engineering

8-6-2013

\title{
The Key Role of Heavy Precipitation Events in Climate Model Disagreements of Future Annual Precipitation Changes in California
}

David W. Pierce

Daniel R. Cayan

Tapash Das

Edwin P. Maurer

Santa Clara University, emaurer@scu.edu

Norman L. Miller

See next page for additional authors

Follow this and additional works at: https://scholarcommons.scu.edu/ceng

Part of the Civil and Environmental Engineering Commons

\section{Recommended Citation}

Pierce, D., D.R. Cayan, T. Das, E.P. Maurer, N.L. Miller, Y. Bao, M. K, K. Yoshimura, M.A. Snyder, L.C. Sloan, G. Franco, M. Tyree, 2013, The key role of heavy precipitation events in climate model disagreements of future annual precipitation changes in California, Journal of Climate 26, 5879-5896. doi:10.1175/jcli-d-12-00766.1, 2013.

(c) Copyright 2013 American Meteorological Society (AMS).

This Article is brought to you for free and open access by the School of Engineering at Scholar Commons. It has been accepted for inclusion in Civil Engineering by an authorized administrator of Scholar Commons. For more information, please contact rscroggin@scu.edu. 


\section{Authors}

David W. Pierce, Daniel R. Cayan, Tapash Das, Edwin P. Maurer, Norman L. Miller, Yan Bao, M. Kanamitsu, Kei Yoshimura, Mark A. Snyder, Lisa C. Sloan, Guido Franco, and Mary Tyree 


\title{
The Key Role of Heavy Precipitation Events in Climate Model Disagreements of Future Annual Precipitation Changes in California
}

\author{
David W. Pierce, ${ }^{*}$ DANiel R. CAyan, ${ }^{+}$TAPash Das, ${ }^{\#}$ Edwin P. MAurer, ${ }^{@}$ Norman L. Miller, ${ }^{\&}$ \\ YAN BAO, ${ }^{\&}$ M. KANAMITSU, ${ }^{*} * *$ KeI YOSHIMURA, ${ }^{*}$ MARK A. SNYdER, ${ }^{++}$LISA C. SlOAN, ${ }^{++}$ \\ GUIDO FRANCO, ${ }^{\# \#}$ AND MARY TYREE* \\ * Scripps Institution of Oceanography, La Jolla, California \\ ${ }^{+}$Scripps Institution of Oceanography, and U.S. Geological Survey, La Jolla, California \\ \# Scripps Institution of Oceanography, La Jolla, and CH2M HILL, Inc., San Diego, California \\ ${ }^{\circledR}$ Santa Clara University, Santa Clara, California \\ ${ }^{\&}$ University of California, Berkeley, Berkeley, California \\ ${ }^{++}$University of California, Santa Cruz, Santa Cruz, California \\ \#\# California Energy Commission, Sacramento, California
}

(Manuscript received 25 October 2012, in final form 19 February 2013)

\begin{abstract}
Climate model simulations disagree on whether future precipitation will increase or decrease over California, which has impeded efforts to anticipate and adapt to human-induced climate change. This disagreement is explored in terms of daily precipitation frequency and intensity. It is found that divergent model projections of changes in the incidence of rare heavy $\left(>60 \mathrm{~mm} \mathrm{day}^{-1}\right)$ daily precipitation events explain much of the model disagreement on annual time scales, yet represent only $0.3 \%$ of precipitating days and $9 \%$ of annual precipitation volume. Of the 25 downscaled model projections examined here, 21 agree that precipitation frequency will decrease by the 2060 s, with a mean reduction of $6-14{\text { days } \mathrm{yr}^{-1}}^{-}$. This reduces California's mean annual precipitation by about $5.7 \%$. Partly offsetting this, 16 of the 25 projections agree that daily precipitation intensity will increase, which accounts for a model average $5.3 \%$ increase in annual precipitation. Between these conflicting tendencies, 12 projections show drier annual conditions by the 2060s and 13 show wetter. These results are obtained from 16 global general circulation models downscaled with different combinations of dynamical methods [Weather Research and Forecasting (WRF), Regional Spectral Model (RSM), and version 3 of the Regional Climate Model (RegCM3)] and statistical methods [bias correction with spatial disaggregation (BCSD) and bias correction with constructed analogs (BCCA)], although not all downscaling methods were applied to each global model. Model disagreements in the projected change in occurrence of the heaviest precipitation days $\left(>60 \mathrm{~mm} \mathrm{day}^{-1}\right)$ account for the majority of disagreement in the projected change in annual precipitation, and occur preferentially over the Sierra Nevada and Northern California. When such events are excluded, nearly twice as many projections show drier future conditions.
\end{abstract}

\section{Introduction}

California has taken an aggressive approach to confronting human-induced climate change (e.g., Anderson et al. 2008; Franco et al. 2011). For example, state assembly bill 32 (AB 32) targets reducing greenhouse gas emissions to 1990 levels by 2020. Actions are also being

\footnotetext{
** Deceased.
}

Corresponding author address: David W. Pierce, SIO/CASPO, Mail Stop 0224, La Jolla, CA, 92093-0224.

E-mail: dpierce@ucsd.edu taken to adapt to the anticipated changes, such as taking sea level rise into account in coastal planning.

While it is nearly certain that California's climate will warm in future decades (e.g., Hayhoe et al. 2004; Leung et al. 2004; Solomon et al. 2007; Pierce et al. 2012), projections of annual precipitation change are proving more problematic. Model results diverge significantly, with a model-mean value near zero (e.g., Dettinger 2005). Although a projection of no significant change is as valid as any other, it is worth exploring the origins of this disagreement. We approach the problem using a variety of global models and downscaling techniques to examine how changes in precipitation frequency and intensity on a daily time scale combine to produce the annual change. 
Changes in the frequency and intensity of precipitation events can have a profound impact. Precipitation frequency can affect crops, tourism, and outdoor recreation. More intense rainfall increases the chance of flooding and, lacking adequate reservoir storage, can mean that a larger proportion of total precipitation leaves the region through runoff, becoming unavailable for beneficial use. More intense rainfall and the transition from snow to rain may also reduce groundwater recharge in some locations (Dettinger and Earman 2007).

Numerous studies have examined projected changes in California's monthly or seasonal precipitation due to human-induced climate change, but only a few have examined daily precipitation intensity and frequency (Kim 2005; Hayhoe et al. 2004; Leung et al. 2004). However, the physical processes causing changes in the frequency and intensity of daily precipitation have become better understood in recent years. Warmer air temperatures allow more water vapor in the atmosphere, providing a tendency toward more intense precipitation, although the actual processes controlling extremes depend on changes in temperature, upward velocity, and precipitation efficiency (O'Gorman and Schneider 2009; Muller et al. 2011). Evidence from energy and water balance constraints (Stephens and Hu 2010) and global climate models (Meehl et al. 2005) indicates that climate warming will generally result in greater intensity precipitation events, though it is less clear how these changes will play out regionally. For example, in the region of interest here, the migration of storm tracks poleward implies a shift in precipitation frequency over the U. S. West Coast (e.g., Yin 2005; Salathé 2006; Ulbrich et al. 2008; Bender et al. 2012).

In California some of the projected precipitation changes, particularly in daily extremes, are related to atmospheric rivers of water vapor that originate in the tropics or subtropics and are advected by winds into the west coast of North America (e.g., Ralph and Dettinger 2011). Changes in atmospheric rivers (Dettinger 2011) would be important because they generate many of California's large floods and play a key role in delivering the state's water supply (Ralph and Dettinger 2011, 2012).

Global models can reproduce some large-scale patterns of precipitation and its variability, but typically simulate light precipitation days too frequently and heavy precipitation days too weakly (Sun et al. 2006; Dai 2006). This problem is resolution-dependent; Wehner et al. (2010) showed that intensity is captured better as model resolution increases from $2^{\circ}$ to $\sim 0.5^{\circ}$. Chen and Knutson (2008) emphasized the fundamental problems of comparing station precipitation observations, which are valid at a point, to climate model fields, which are averaged over a grid cell.
Downscaling is often used to address the problem of global model resolution that is too coarse to simulate precipitation intensity accurately. Downscaling is especially needed given California's coastal and interior mountain ranges, which affect precipitation yet are poorly resolved by global climate models. Downscaling can use either statistical methods, which are based on observed relationships between small-scale and largescale processes, or dynamical methods, which use regional finescale climate or weather models driven by global climate models.

Our first goal is to show how downscaled climate simulations project future changes in daily precipitation frequency and intensity over California, and how these combine to produce annual precipitation changes. Since our interest is in water supply issues, we focus on absolute changes using a single threshold for heavy precipitation events across the state, rather than on percentage changes in precipitation relative to the local climatology. (Other investigators might be more interested in the largest local fractional changes, such as how they affect the local ecology.) This means that our analysis also ends up focusing on locations where heavy precipitation occurs, which in California is the Sierra Nevada and the northern part of the state. An analysis that finds heavy precipitation events are important is necessarily intertwined with the location where such events can happen, which is a function of how the regional meteorological setting (e.g., prevalent moisture-bearing wind patterns) interacts with the local topography.

The second goal is to compare how different statistical and dynamical downscaling methods produce changes in precipitation frequency and intensity. We use daily precipitation from two global models dynamically downscaled with three regional climate models, those two same global climate models along with two others statistically downscaled by a technique that preserves the daily sequence of global model precipitation, and those four global models along with 12 more statistically downscaled with a technique that is widely used but does not preserve the daily sequence of precipitation.

Owing to the computational burden of dynamically downscaling with multiple regional models, we limit our analysis to two periods: the historical era (1985-94) and the 2060s. For the same reason we consider only the Special Report on Emissions Scenarios (SRES) A2 emissions forcing scenario (Nakicenovic and Swart 2000). The 2060s is about the last decade when the change in global air temperatures due to anthropogenic forcing is not well separated between different emissions scenarios (Solomon et al. 2007). The same models were used in Pierce et al. (2012) to examine projected seasonal mean and 3-day maximum temperature and precipitation 
TABLE 1. The global general circulation models used in this project, their originating institution, and whether they were downscaled by the indicated method. BCSD: bias correction with spatial disaggregation; BCCA: bias correction with constructed analogs; WRF: Weather Research and Forecasting model; RSM: Regional Spectral Model; RegCM3: Regional Climate Model, version 3.

\begin{tabular}{|c|c|c|c|c|c|c|}
\hline GCM & Institution & BCSD & BCCA & WRF & RSM & RegCM3 \\
\hline $\begin{array}{l}\text { BCCR Bergen Climate Model, version } 2.0 \\
\text { (BCM 2.0) }\end{array}$ & $\begin{array}{l}\text { Bjerknes Centre for Climate Research } \\
\text { (BCCR), Bergen, Norway }\end{array}$ & $\mathrm{Y}$ & & & & \\
\hline $\begin{array}{l}\text { CCCma Coupled General Circulation } \\
\text { Model, version 3.1 (CGCM3.1) }\end{array}$ & $\begin{array}{l}\text { Canadian Centre for Climate Modelling } \\
\text { and Analysis (CCCma), Victoria, British } \\
\text { Columbia, Canada }\end{array}$ & $\mathrm{Y}$ & & & & \\
\hline $\begin{array}{l}\text { Centre National de Recherches } \\
\text { Météorologiques Coupled Global } \\
\text { Climate Model, version } 3 \text { (CNRM-CM3) }\end{array}$ & Météo-France, Toulouse, France & $\mathrm{Y}$ & $\mathrm{Y}$ & & & \\
\hline CSIRO Mark, version 3.0 (CSIRO Mk3.0) & $\begin{array}{l}\text { Commonwealth Scientific and Industrial } \\
\text { Research Organisation (CSIRO), } \\
\text { Melbourne, Australia }\end{array}$ & $\mathrm{Y}$ & & & & \\
\hline GFDL Climate Model, version 2.0 (CM2.0) & $\begin{array}{l}\text { Geophysical Fluid Dynamics Laboratory, } \\
\text { Princeton (GFDL), New Jersey, } \\
\text { United States }\end{array}$ & $\mathrm{Y}$ & & & & \\
\hline GFDL Climate Model, version 2.1 (CM2.1) & $\begin{array}{l}\text { GFDL, Princeton, New Jersey, } \\
\text { United States }\end{array}$ & $\mathrm{Y}$ & $\mathrm{Y}$ & $\mathrm{Y}$ & $\mathrm{Y}$ & $\mathrm{Y}$ \\
\hline GISS Model E-R (GISS ER) & $\begin{array}{l}\text { NASA/Goddard Institute for Space Studies } \\
\text { (GISS), New York, United States }\end{array}$ & $\mathrm{Y}$ & & & & \\
\hline $\begin{array}{l}\text { INM Coupled Model, version } 3.0 \\
\text { (INM-CM 3.0) }\end{array}$ & $\begin{array}{l}\text { Institute of Numerical Mathematics (INM), } \\
\text { Moscow, Russia }\end{array}$ & $\mathrm{Y}$ & & & & \\
\hline $\begin{array}{l}\text { IPSL Coupled Model, version } 4 \\
\text { (IPSL CM4) }\end{array}$ & $\begin{array}{l}\text { L'Institut Pierre Simon Laplace (IPSL), } \\
\text { Paris, France }\end{array}$ & $\mathrm{Y}$ & & & & \\
\hline $\begin{array}{l}\text { Model for Interdisciplinary Research on } \\
\text { Climate 3.2, medium-resolution version } \\
\text { [MIROC 3.2(medres)] }\end{array}$ & $\begin{array}{l}\text { Center for Climate System Research, } \\
\text { Tokyo, Japan }\end{array}$ & $\mathrm{Y}$ & & & & \\
\hline $\begin{array}{l}\text { MIUB ECHAM and the global Hamburg } \\
\text { Ocean Primitive Equation (ECHO-G) }\end{array}$ & $\begin{array}{l}\text { Meteorological Institute of the University } \\
\text { of Bonn (MIUB), Bonn, Germany }\end{array}$ & $\mathrm{Y}$ & & & & \\
\hline MPI ECHAM5 & $\begin{array}{l}\text { Max Planck Institute for Meteorology } \\
\text { (MPI), Hamburg, Germany }\end{array}$ & $\mathrm{Y}$ & & & & \\
\hline $\begin{array}{l}\text { Meteorological Research Institute Coupled } \\
\text { General Circulation Model, version } \\
\text { 2.3.2a (MRI CGCM2.3.2) }\end{array}$ & $\begin{array}{l}\text { Meteorological Research Institute, } \\
\text { Tsukuba, Ibaraki, Japan }\end{array}$ & $\mathrm{Y}$ & & & & \\
\hline $\begin{array}{l}\text { NCAR Community Climate System Model, } \\
\text { version } 3 \text { (CCSM3) }\end{array}$ & $\begin{array}{l}\text { National Center for Atmospheric Research, } \\
\text { Boulder (NCAR), Colorado, } \\
\text { United States }\end{array}$ & $\mathrm{Y}$ & $\mathrm{Y}$ & Y & $\mathrm{Y}$ & \\
\hline $\begin{array}{l}\text { NCAR Parallel Climate Model, version } 1 \\
\text { (PCM1) }\end{array}$ & NCAR, Boulder, CO, United States & $\mathrm{Y}$ & $\mathrm{Y}$ & & & \\
\hline $\begin{array}{l}\text { Third climate configuration of the Met } \\
\text { Office Unified Model (UKMO HadCM3) }\end{array}$ & $\begin{array}{l}\text { Met Office, Exeter, Devon, United } \\
\text { Kingdom }\end{array}$ & $\mathrm{Y}$ & & & & \\
\hline
\end{tabular}

changes in California; this work extends that previous study by examining how changes in precipitation frequency and intensity on a daily time scale combine to produce overall precipitation changes.

\section{Data and methods}

The models and downscaling methods used in this work are the same as used in Pierce et al. (2012); we refer the reader to that work for a detailed description. All downscaling is to $\sim 12 \mathrm{~km}$ spatial resolution. In cases where more than one ensemble member was available for downscaling, we used ensemble number 1 from the global model.
The global models and downscaling methods applied to each are listed in Table 1. Each combination of global model and downscaling technique will be referred to as a "model projection." Dynamically downscaled results are obtained using three regional climate models (RCMs): 1) version 3 of the Regional Climate Model (RegCM3), which is originally based on the fifthgeneration Pennsylvania State University-National Center for Atmospheric Research Mesoscale Model (MM5) (Pal et al. 2007); 2) the NCAR-National Centers for Environmental Prediction (NCEP)-Forecast Systems Laboratory (FSL) Weather Research and Forecasting (WRF) model (Skamarock et al. 2008); and 3) the Regional Spectral Model (RSM) (Kanamitsu et al. 2005), 
which is a version of the NCEP global spectral model optimized for regional applications. The ability of the regional models to reproduce observed climatology given historical reanalysis as forcing was examined in Miller et al. (2009), who concluded that, while all models have limitations, they do a credible job overall. In total, we examine five dynamically downscaled model projections.

Two methods of statistical downscaling are used: 1) bias correction with constructed analogs (BCCA) (Hidalgo et al. 2008; Maurer et al. 2010), which downscales fields by linearly combining the closest analogs in the historical record, and 2) bias correction with spatial disaggregation (BCSD) (Wood et al. 2002, 2004), which generates daily data from monthly GCM output by selecting a historical month and rescaling the daily precipitation to match the monthly value and so does not preserve the original global model sequence of daily precipitation. The historical month chosen is conditioned on monthly precipitation amount, so the number of zero precipitation days can change as precipitation changes, but the precipitation intensity changes in BCSD are less directly connected to the GCM results than in the other methods. Maurer and Hidalgo (2008) compared results of using BCCA and BCSD and concluded that they have comparable skill in producing downscaled monthly temperature and precipitation. In total, we analyze 4 model projections with BCCA and another 16 with BCSD.

BCCA and BCSD downscale to the same $1 / 8^{\circ} \times 1 / 8^{\circ}$ $(\sim 12 \mathrm{~km})$ latitude-longitude grid used in the Hamlet and Lettenmaier (2005) observational dataset. RegCM3, WRF, and RSM each have their own finescale grid $O(12 \mathrm{~km})$ but are not coincident. For consistency and ease of comparison with observations, the dynamically downscaled fields were regridded to the same $1 / 8^{\circ} \times 1 / 8^{\circ}$ latitude-longitude grid used for the statistical methods and observations before analysis.

Natural climate variability due to such phenomena as the El Niño-Southern Oscillation (ENSO) and the Pacific decadal oscillation (PDO) is not of direct interest here, so in order to minimize these effects we generally average our results over multiple model projections. Since different projections have different phases of ENSO, PDO, or other natural climate modes of variability, averaging across model projections tends to reduce the influence of natural variability on our results.

\section{Bias correction}

Biases in downscaled precipitation fields can lead to inaccurate hydrological impacts, especially given the nonlinear nature of runoff. Since the project's purpose was to focus on hydrological and other applications, all of the precipitation fields shown here are bias corrected (Panofsky and Brier 1968; Wood et al. 2002, 2004;
Maurer 2007; Maurer et al. 2010). Such biases can be created by the downscaling method, but often reflect biases in the original global model (e.g., Wood et al. 2004; Duffy et al. 2006; Liang et al. 2008). Details of the bias correction procedure are given in Pierce et al. (2012).

\section{Results}

\section{a. Change in precipitation frequency}

Current GCMs overpredict the number of days with a small amount of precipitation (e.g., Sun et al. 2006; Dai 2006; Chen and Knutson 2008; cf. Wehner et al. 2010). Typically this problem is addressed by defining a threshold below which a model is considered to have zero precipitation. For example, Leung et al. (2004) used $0.01 \mathrm{~mm} \mathrm{day}^{-1}$, Caldwell et al. (2009) used $0.1 \mathrm{~mm} \mathrm{day}^{-1}$, and Kim (2005) used $0.5 \mathrm{~mm}$ day $^{-1}$. Station observations have limited resolution too; in the global summary of day (GSOD) dataset no values less than $0.25 \mathrm{~mm} \mathrm{day}^{-1}$ are reported, while the NOAA cooperative observing stations typically report no values less than $0.1 \mathrm{~mm} \mathrm{day}^{-1}$. We use a threshold of $0.1 \mathrm{~mm}$ day $^{-1}$ below which model precipitation values are taken to be zero.

Figure 1 shows the climatological frequency (days $\mathrm{yr}^{-1}$ ) of days with precipitation less than $0.1 \mathrm{~mm}$ day $^{-1}$, hereafter referred to as "zero precipitation days." Figure 1a is the mean across all model simulations for the historical period, and Fig. 1b is from the Hamlet and Lettenmaier (2005) observations over the period 1970-99. The two fields are similar, but all model fields are bias corrected (Pierce et al. 2012), which reduces the disagreement between models and observations. It makes little sense to reformulate a non-bias-corrected version of BCSD or BCCA, but the dynamical downscaling methods apply bias correction after the simulations are performed. Figures $1 \mathrm{c}$ and $1 \mathrm{~d}$ show the number of zero precipitation days from the dynamically downscaled models with and without bias correction, respectively. With bias correction the number of zero-precipitation days matches observations much better than before bias correction, even though the precipitation rate is bias corrected rather than the number of zero precipitation days. The non-bias-corrected fields have too few zero precipitation days. Besides the propensity for models to simulate too many light precipitation days, this reflects the tendency of dynamic downscaling in this region to produce more precipitation than observed (Miller et al. 2009). Figure 1e shows histograms of percentage of grid points in the domain that experience the indicated rate of zeroprecipitation days per year. The non-bias-corrected histogram (green triangles) is a poor representation of the observed distribution (red circles). Bias correction improves this substantially (purple crosses), although 
a) All models

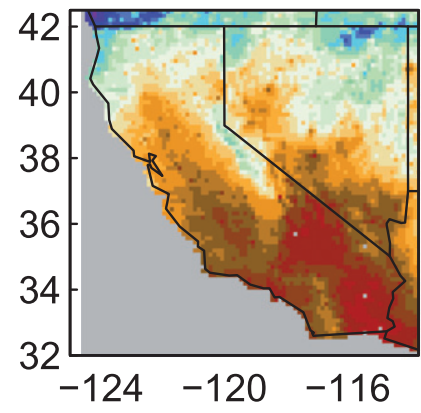

c) BC-dynam

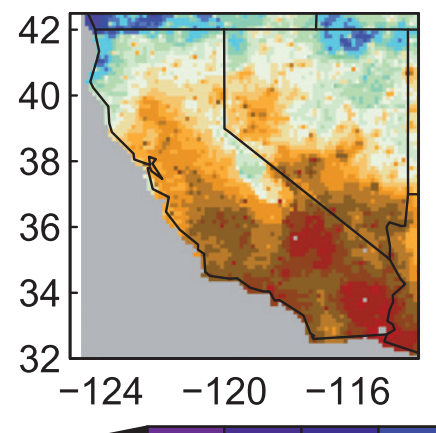

b) Obs.

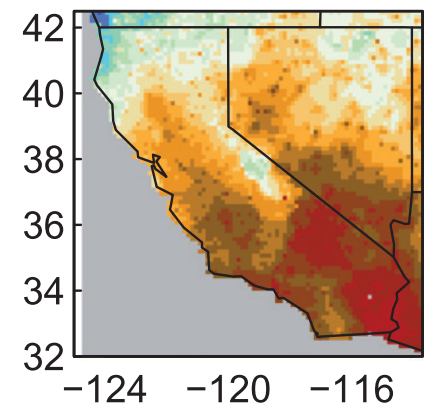

d) non-BC dynan

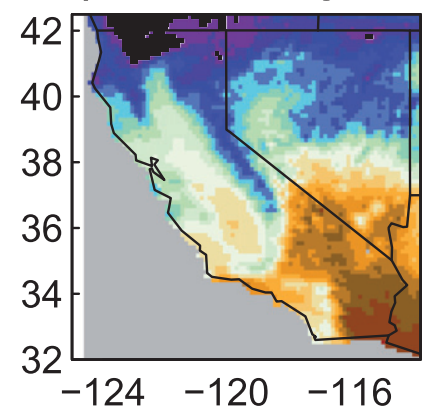

e) Frequency of occurrence

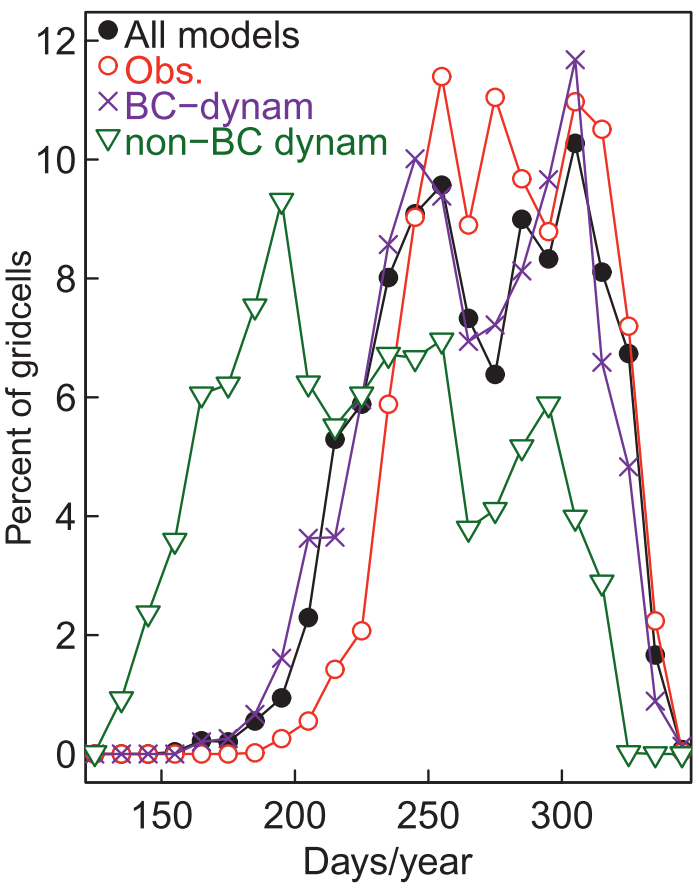

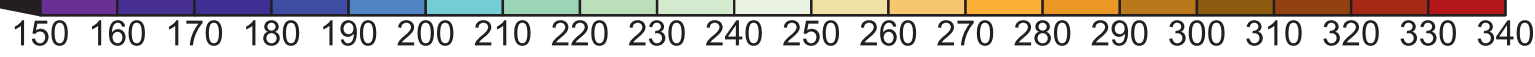
Days/year

FIG. 1. Climatological number of zero-precipitation days per year from (a) all model runs over the historical period, (b) observations 1970-99; (c) only the dynamically downscaled runs over the historical period, with bias correction; and (d) only the dynamically downscaled runs, without bias correction: color scale is along the bottom. (e) Histogram showing the frequency of occurrence (expressed as the percent of grid cells) experiencing the indicated number of zero-precipitation days per year.

differences in the distributions are still evident, particularly around 220 and 270 days $\mathrm{yr}^{-1}$.

Figure 2 shows the change (future minus historical) in annual precipitation amount and frequency of zeroprecipitation days along with the empirical cumulative distribution function (CDF) of these quantities. All values are averaged across model projections. The number of zero-precipitation days increases by $6-14$ days per year over most of the domain, especially Northern California and the Sierra Nevada, which is an increase of $3 \%-6 \%$ (Fig. 2e). Yet model-mean precipitation in this region increases slightly, which implies that precipitation intensity has increased. Similarly, the southern coastal regions show pronounced drying, but do not show the largest increase in zero-precipitation days. Overall, $73 \%$ of the grid cells experience decreasing precipitation, and the median change in number of zeroprecipitation days is 8 days $\mathrm{yr}^{-1}$ (about a $3 \%$ increase).

The effect of each downscaling technique on the change in number of zero precipitation days is shown in Fig. 3, illustrated for the two global models that were downscaled with the most techniques (CCSM3 and GFDL
CM2.1). The original global model field is shown in the leftmost column for comparison. Bias correction with spatial disaggregation (BCSD) tends to show the least increase in zero-precipitation days while bias correction with constructed analogs (BCCA) tends to show the most, although the differences are small. The decreasing number of zero-precipitation days in the interior southeast with RSM downscaling is associated with a more active North American monsoon. As discussed in Pierce et al. (2012), this is primarily a summer response that is seen more clearly with dynamical downscaling than statistical downscaling and is relatively more influenced by the individual dynamic downscaling model being used then by the global GCM being downscaled. This suggests that the details of the projected summer monsoonal changes are sensitive to the cloud and precipitation parameterizations used in the regional dynamical models.

\section{b. Effect of downscaling on daily precipitation intensity}

Figure 4 shows the way different downscaling techniques alter the global model's daily precipitation 
a) Change annual precip

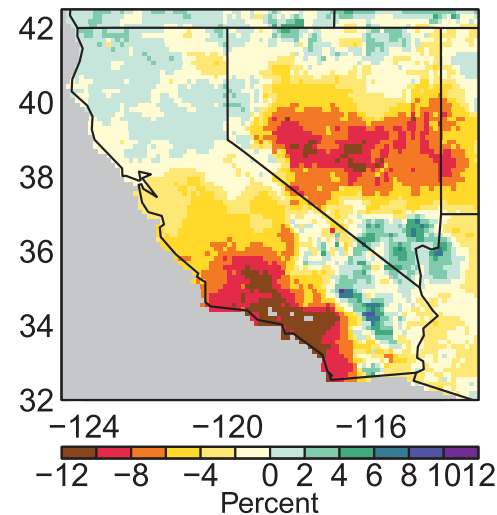

b) CDF precip change

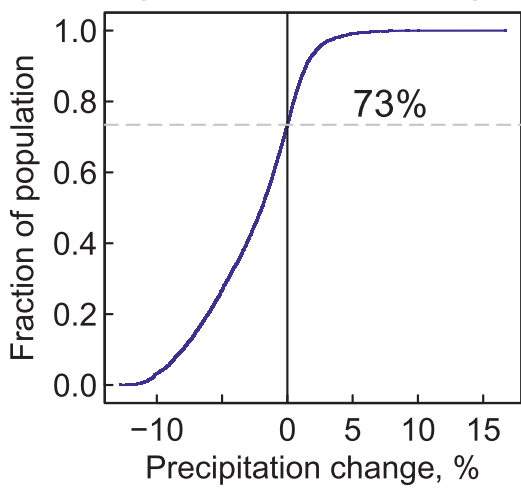

c) Change zero-P days

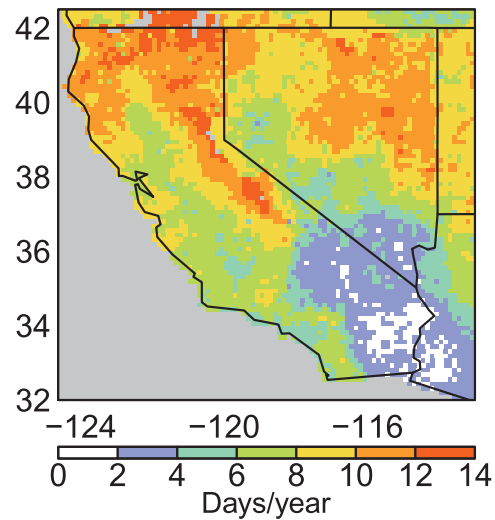

d) CDF change zero-p day

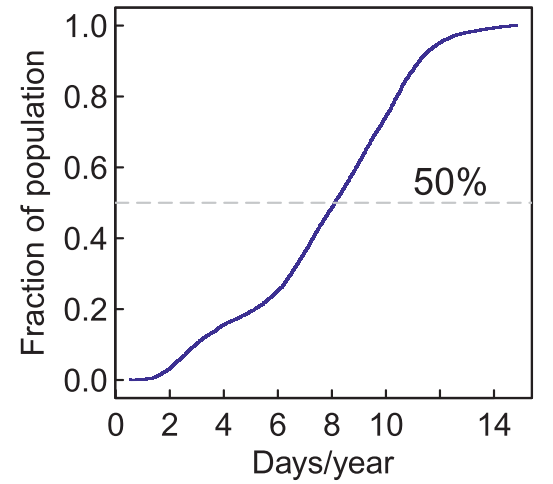

e) Change zero-P days $\%$

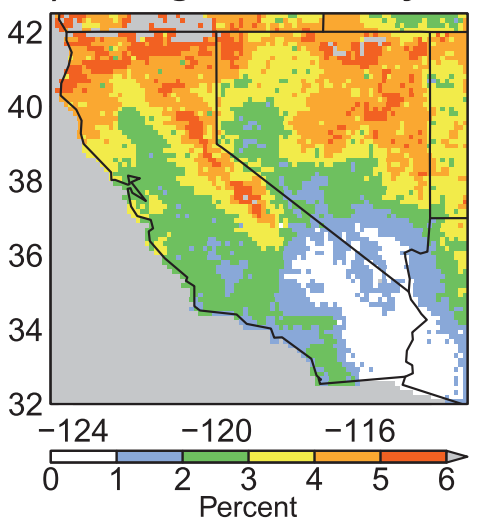

f) CDF change zero-p day

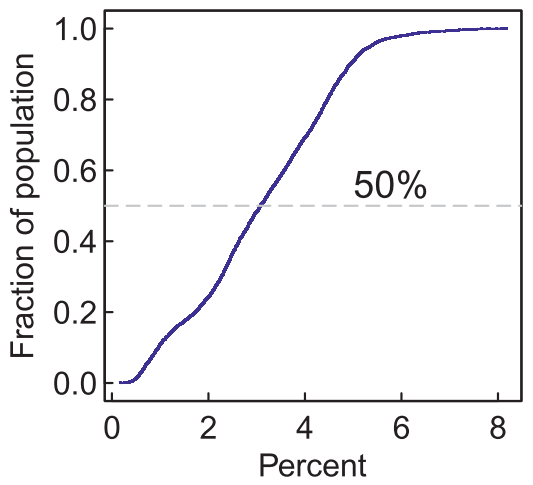

FIG. 2. (a) Change (future era minus historical) in annual precipitation (\%). (b) Empirical cumulative distribution function (CDF) of the precipitation changes; $73 \%$ of the grid cells experience decreasing precipitation. (c) Change in number of zero precipitation days per year.

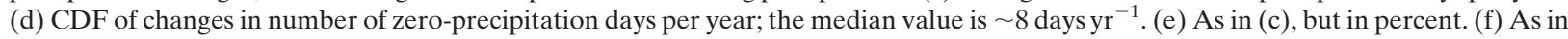
(d), but in percent. All values are averaged across all downscaling methods and models.

intensity. The colored maps show the ratio of downscaled precipitation rate in a grid cell to the global model's precipitation rate on the same day and interpolated to the same grid cell, averaged over days with precipitation. We term this the "amplification factor." The line plots show histograms of the amplification factor across all grid cells for each downscaling technique. BCSD results are excluded since they do not preserve the daily sequence of GCM precipitation. Results are broken out by low, medium, and high tercile of the original global model precipitation intensity in the grid cell.

The amplification factor varies spatially and nonlinearly with the magnitude of the GCM's precipitation. Each dynamical downscaling method changes the global model precipitation signal in a characteristic way, though all amplify the global model's precipitation rate in the lowest tercile. In the Sierra Nevada and the northern coastal mountains, dynamic downscaling amplifies precipitation rates in the low tercile by 4 or more compared to the original GCM. In the medium and high terciles the dynamically downscaled simulations exhibit successively greater fractional precipitation rate reductions in rain shadow regions with respect to the original GCMs. In such locations the GCMs typically produce unrealistically heavy precipitation due to inadequately resolved topography.

The amplification factors of the three dynamical methods are similar to each other, and all differ from the BCCA statistical method, a feature particularly evident in the histograms. BCCA has a more linear relationship between global and downscaled precipitation intensity, especially in mountainous terrain such as the Sierra Nevada and coastal range, where nonlinearities in the dynamical methods are pronounced.

The largest nonlinearities in the BCCA amplification factor are in the rain shadow regions. The real world shows this behavior as well; an analysis of the Hamlet and Lettenmaier (2005) data shows that, as regional averaged precipitation increases, the contrast between precipitation in the mountains and precipitation in the 

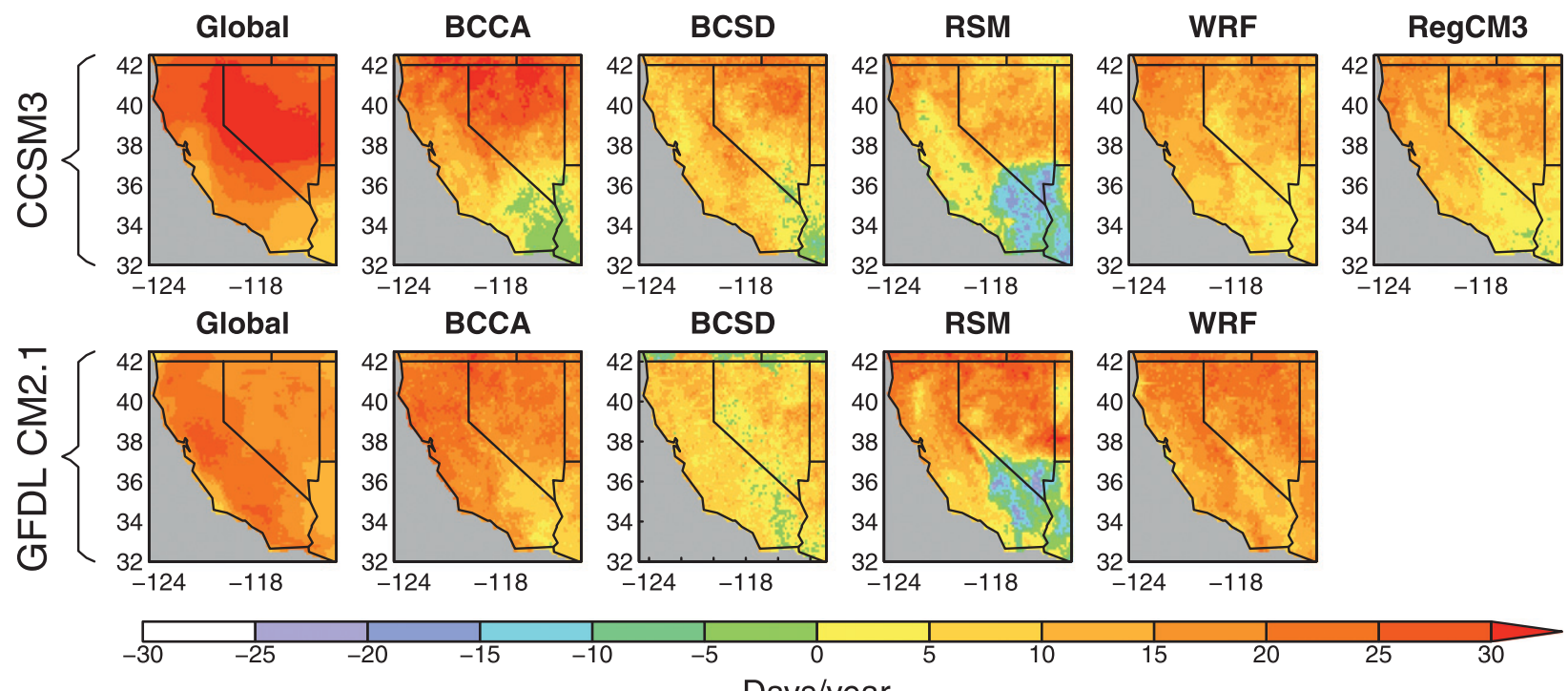

FIG. 3. Change in the number of zero-precipitation days $\left(\right.$ days $\left.\mathrm{yr}^{-1}\right)$, future era minus historical, as a function of global model (labels on the left) and downscaling technique.

rain shadow increases as well (not shown). BCCA, being based on observations, mimics this behavior.

\section{c. Future change in daily precipitation intensity}

Figure 5 shows the change (future minus historical) in the fraction of precipitating days that have precipitation of the indicated intensity $\left(\mathrm{mm} \mathrm{day}^{-1}\right)$ averaged across all model projections. In most locations the fractional occurrence of amounts less than $10 \mathrm{~mm}_{\text {day }}{ }^{-1}$ decreases. However, this is compensated for by a greater occurrence of days with $20 \mathrm{~mm}$ day $^{-1}$ or more. Over much of the dry interior, values greater than $100 \%$ indicate that, when considering only days with precipitation, the rate of days with heavy precipitation more than doubles. Elsewhere, such days typically increase by $25 \%-50 \%$.

Figure 2 showed that the number of days with precipitation generally declines, so the increase in fraction of precipitating days with heavy precipitation does not necessarily mean that the actual number of days per year with heavy precipitation increases (i.e., if it rains half as often but the fraction of rainy days that have heavy rain doubles, then the number of heavy rain days per year is unchanged.) To clarify this, Fig. 6 shows the change in precipitation intensity expressed as the change (future minus historical) in number of days per year, averaged across model projections. Over most of California, especially the Sierra Nevada and northern coastal regions (which experience most of California's precipitation) the number of days with $0.1-20 \mathrm{~mm} \mathrm{day}^{-1}$ of precipitation decreases, while days with $60 \mathrm{~mm} \mathrm{day}^{-1}$ or more increase. Because heavy precipitation days are rare, the increase in number of days per year is low. In all classes of precipitation intensity, Southern California experiences the least change (Fig. 6, right panel), while Nevada experiences the greatest decrease in light precipitation days and Northern California experiences the greatest increase in heavy precipitation days.

The effect of downscaling technique on changes in precipitation intensity is shown in Fig. 7. For brevity, only changes in the lowest $\left(0.1-5 \mathrm{~mm} \mathrm{day}^{-1}\right)$ and highest $\left(60+\mathrm{mm} \mathrm{day}^{-1}\right)$ intensity bins from Fig. 6 are shown. The downscaled change in California's average annual precipitation computed by each method is given in the panel title, for reference. Away from the summer monsoon region, the different downscaling techniques consistently simulate fewer light precipitation days in both global models. However, results for the strongest precipitation intensities are not consistent, either across different downscaling techniques or for different global models across a single downscaling technique. This suggests that inconsistencies in the way changes in heavy precipitation events are simulated could be an important source of model disagreement on future precipitation changes, a point explored further below. For GFDL, the different downscaling methods produce annual mean changes from $-16.6 \%$ to $-2.3 \%$; for CCSM 3 , the range is from $-17.9 \%$ to $8.7 \%$. Therefore, we see that, even given the same global model data as input, downscaling can produce a wide range of net annual precipitation changes.

\section{$d$. The combined effect of frequency and intensity}

The projected change in California's annual mean precipitation shows little agreement across models (e.g., Dettinger 2005). Yet our results indicate that models 


\section{Low tercile}
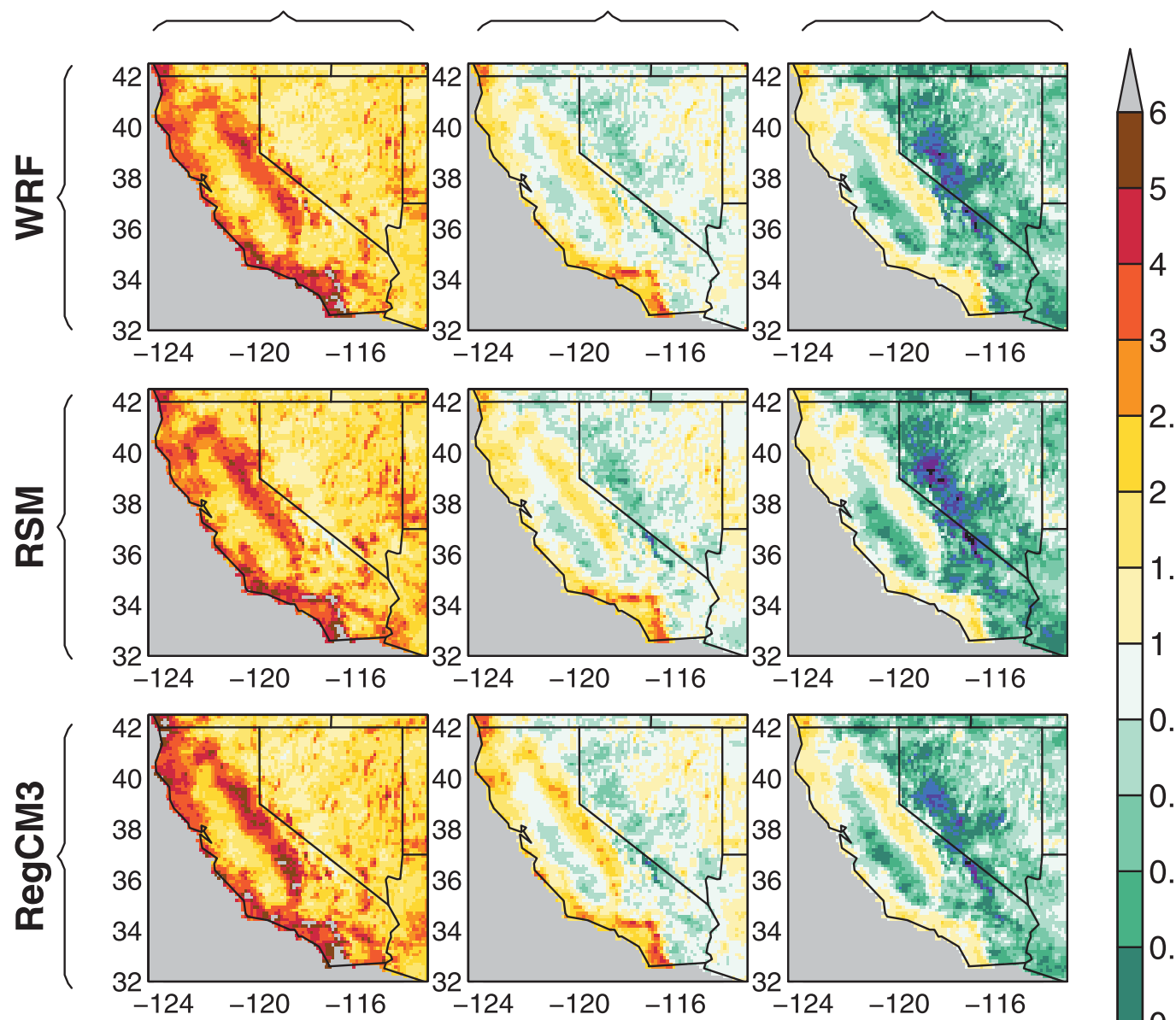

$-1.5$

훙
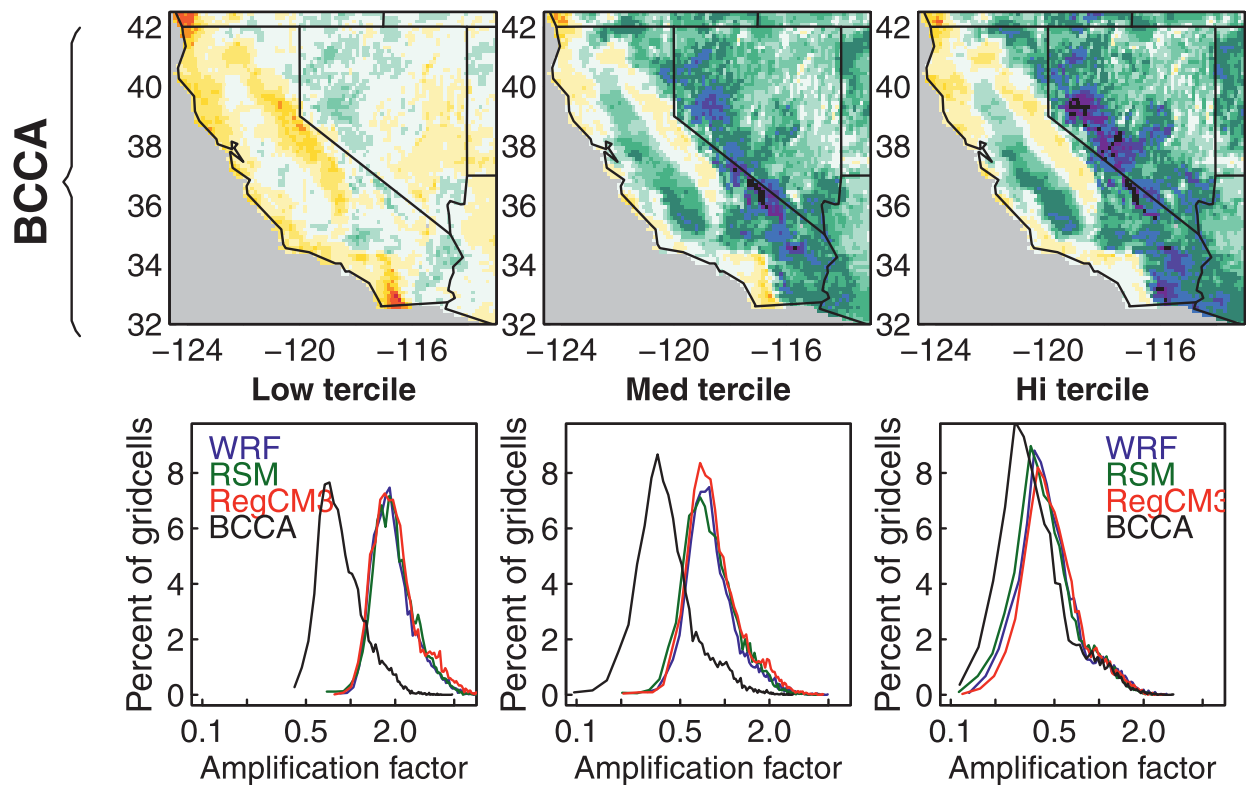

$-0.25$

0.2

0.167

0.142

FIG. 4. The mean ratio of downscaled to global model daily precipitation (computed on days with precipitation), termed the "amplification factor" (maps and color scale). Rows correspond to the downscaling method; WRF, RSM, and RegCM3 are dynamical methods, while BCCA is a statistical method. When the downscaling method was applied to more than one global model, the mean across global models is shown. Columns correspond to terciles of the global precipitation amount in each grid cell for the day being downscaled. Line plots below the maps are histograms of the amplification factor for the different downscaling methods taken across all grid cells, for the indicated tercile of global precipitation amount. 
$0.1-5 \mathrm{~mm} / \mathrm{day}$

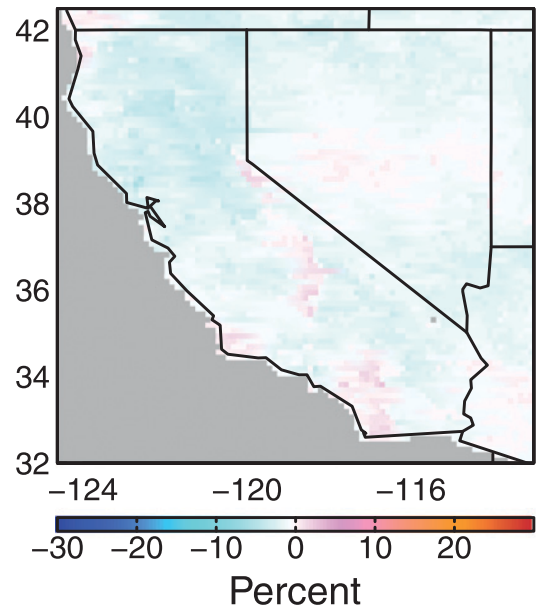

20-40 $\mathrm{mm} /$ day

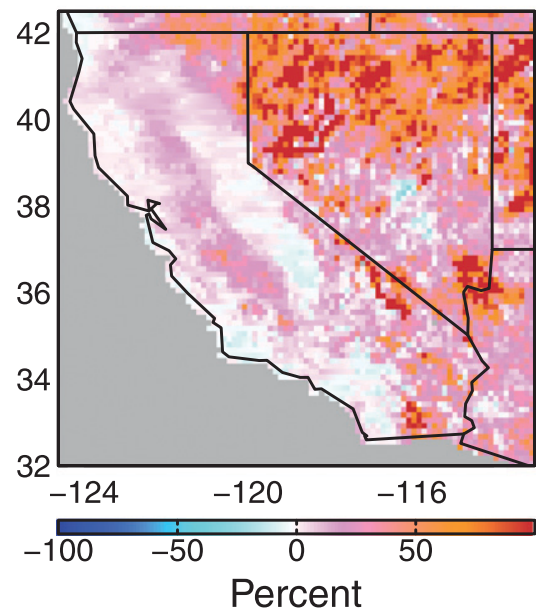

5-10 mm/day

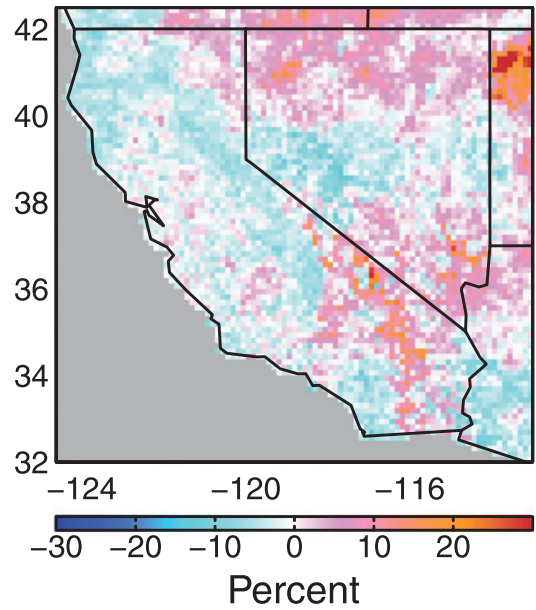

40-60 $\mathrm{mm} /$ day

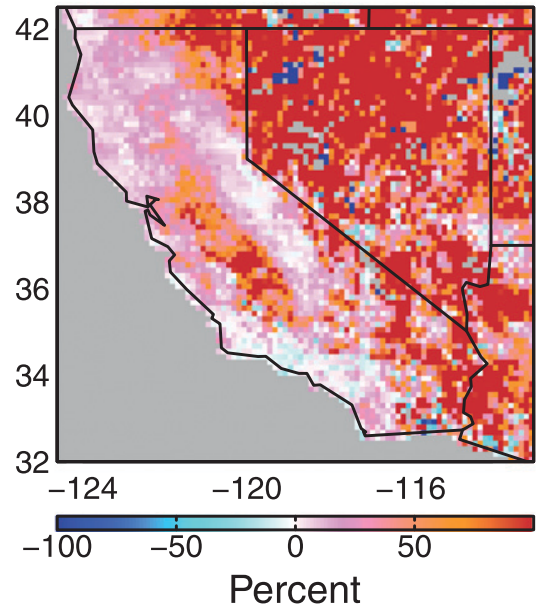

10-20 mm/day

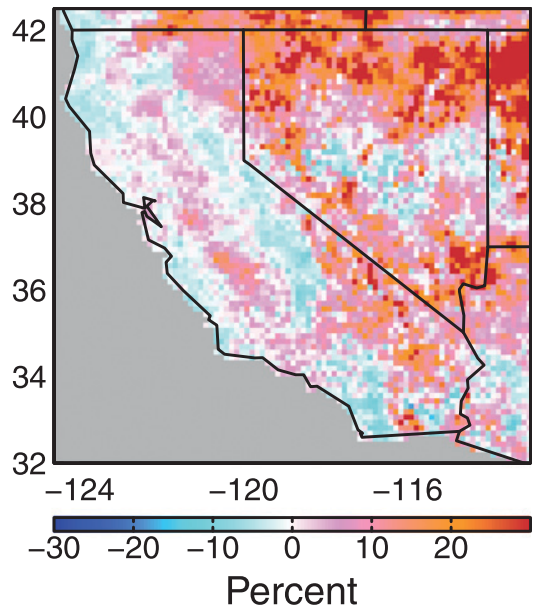

$60+\mathrm{mm} /$ day

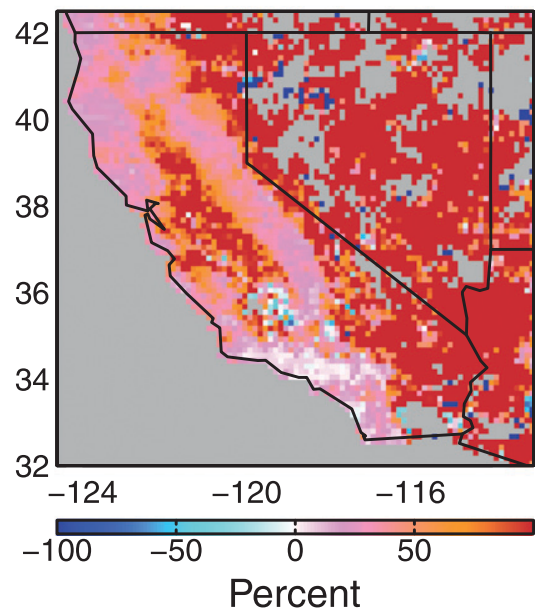

FIG. 5. Change (future minus historical era) in the incidence of the indicated precipitation rate, averaged across all model projections, expressed as a function of the percent of precipitating days (i.e., a value of $100 \%$ indicates that twice as many precipitating days have the indicted rate).

agree that precipitation frequency will decrease and (to a lesser extent) daily intensity will increase. Since the annual precipitation amount is determined by the frequency and intensity of precipitation events, is this a contradiction?

To sensibly compare the effects of changes in frequency and intensity on annual precipitation requires expressing quantities in the same units. We linearize the problem by assuming that that loss of a precipitating day in the future decreases the total annual precipitation by an amount equal to the average rainy-day precipitation in that day's month during the historical period. (The day's month is used because, for example, loss of a July precipitating day typically has less effect on the annual average than loss of a February precipitating day.) The effects of changes in precipitation intensity are then calculated as the actual change in precipitation minus the contribution due to the change in number of precipitating days.

Figure 8 shows the effect of the change in Californiaaveraged precipitation frequency (Fig. 8a) and intensity (Fig. 8b) on total annual precipitation (Fig. 8c). Of the 25 model projections, 21 show a negative tendency in annual precipitation due to fewer days with precipitation, with a mean decline of $32 \mathrm{~mm} \mathrm{yr}^{-1}(5.7 \%$ of the annual total precipitation of $557 \mathrm{~mm}$ ). Sixteen model projections show greater precipitation intensity, which accounts for an increase of $29 \mathrm{~mm} \mathrm{yr}^{-1}(5.3 \%)$ in the annual total. When these competing tendencies are added together the results are distributed around zero, with 12 models showing drier future conditions and 13 showing wetter. Although the small sample of BCCA 

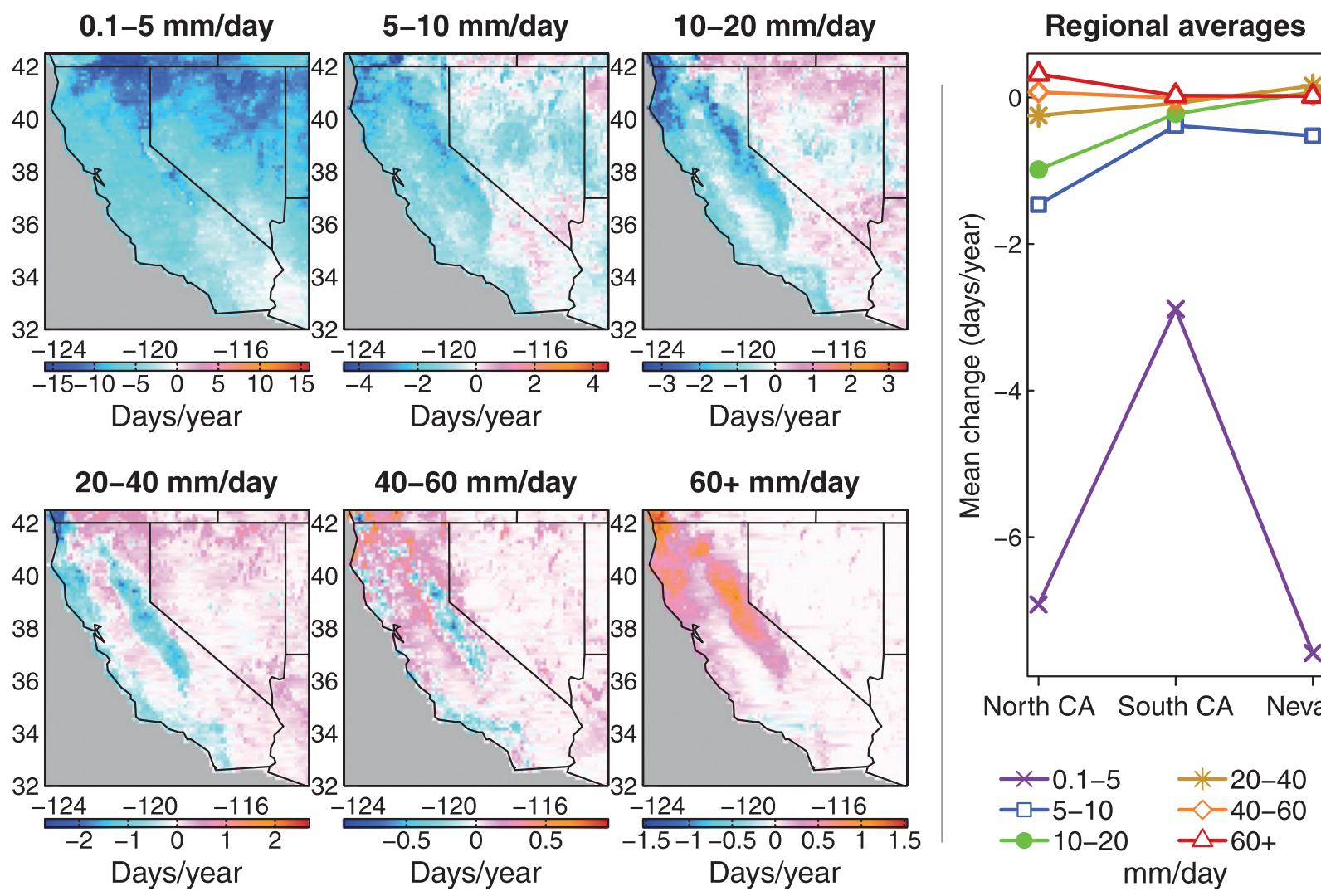

FIG. 6. (left) Change $\left(\right.$ days $\mathrm{yr}^{-1}$ ) in incidence of indicated precipitation intensity, future minus historical era. (right) Regional average of the data in the left panels as a function of precipitation intensity. The dividing latitude between Northern and Southern California is taken as $36^{\circ} \mathrm{N}$.

results prevents definitive conclusions, Fig. $8 \mathrm{~b}$ suggests that BCCA may produce less increase in precipitation intensity than other methods. (This is consistent with Fig. 7 for the CCSM3 model, but not for GFDL.)

The inference from Fig. 7 was that model disagreement between projected changes in California's annual precipitation may arise from the relatively few precipitation events $>60 \mathrm{~mm} \mathrm{day}^{-1}$. This can be tested by computing the change in annual precipitation only including grid cells and days ("grid cell-days") when the grid cell's daily precipitation is less than some cutoff value. Results are shown in Fig. 9, with the precipitation cutoff increasing from 5 to $60 \mathrm{~mm} \mathrm{day}^{-1}$. At the lower cutoffs the models overwhelmingly agree on the sign of the annual change. Even when all grid cell-days with precipitation less than $60 \mathrm{~mm}$ day $^{-1}$ are included (99.7\% of all possible grid cell-days), almost 1.8 times as many models show a precipitation decrease as an increase. Only when the final $0.3 \%$ of grid cell-days with heaviest precipitation are included do the models disagree, with half showing an annual precipitation increase and half showing a decrease. These events occur only rarely, but have a strong influence on the annual precipitation change.
Precipitation events $>60 \mathrm{~mm}$ day $^{-1}$ occur preferentially in the Sierra Nevada and northern coastal regions (Fig. 10; cf. Ralph and Dettinger 2012). On average, they occur about once in every 50-200 days in the northern coastal and Sierra Nevada regions. When considering precipitating days only (Fig. 10b), such events are about one in every $10-50$ precipitating days in the northern coastal, Sierra Nevada, and Los Angeles coastal mountain regions. The Hamlet and Lettenmaier (2005) dataset indicates that typically about $9 \%$ of California's total annual precipitation volume falls during such days. The cumulative distribution functions (Fig. 10c) indicate that the relationship between the occurrence rate (expressed as a 1 -in- $N$ days rate) and the fraction of grid cells experiencing that occurrence rate or higher is approximately exponential. In other words, high occurrence rates $(\operatorname{small} N)$ are concentrated in a small region, and the occurrence rate drops dramatically as more grid cells are considered.

\section{e. Changes in precipitation frequency and intensity over the year}

Most of California's precipitation falls during the cool months (October-April). Figure 11 shows the change in 

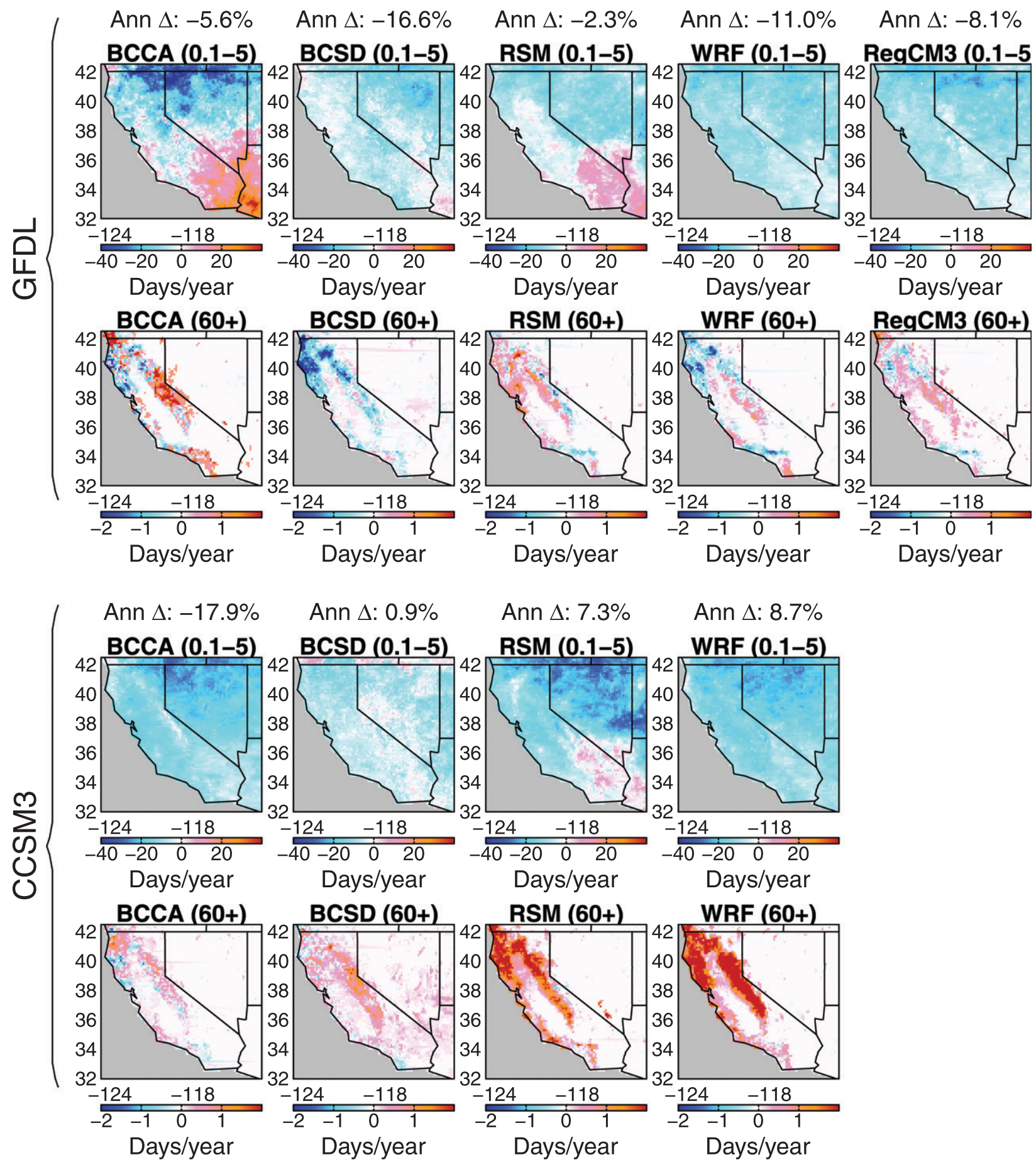

FIG. 7. The effect of different downscaling techniques on changes (days $\mathrm{yr}^{-1}$ ) in precipitation intensity in the lowest and highest bins from Fig. 6 (0.1-5 and 60+ $\mathrm{mm} \mathrm{day}^{-1}$, respectively). The upper set of panels shows results from the GFDL CM2.1 global model; the lower set shows results from the CCSM3 global model. The mean change (future - historical era) in California annual precipitation obtained by each downscaling method is noted in the title.

precipitation by month (top row), change in the number of days with nonzero precipitation (middle row), and 50th and 95th percentiles of precipitation on days with nonzero precipitation (bottom row). Values are averaged over four representative climate regions identified by Abatzoglou et al. (2009), see Fig. 12, which are based on the covariance of anomalous precipitation and temperature over the state. Only BCCA and dynamically 
a) Change from \# zero days

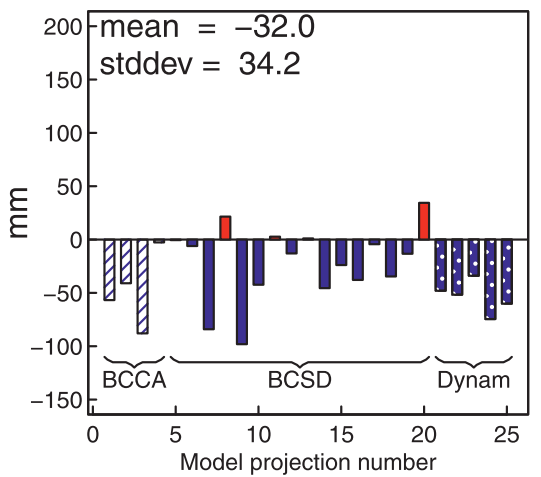

b) Change from intensity

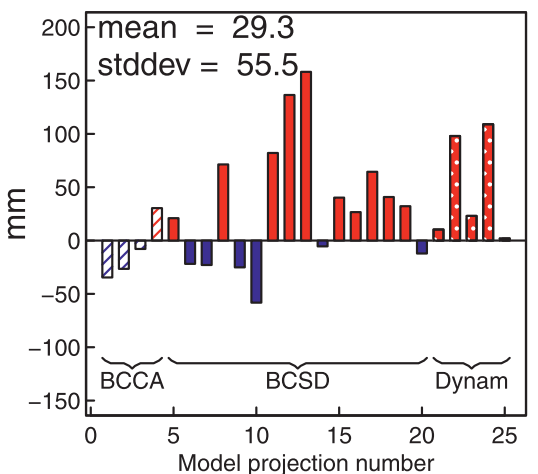

c) Total change $(a+b)$

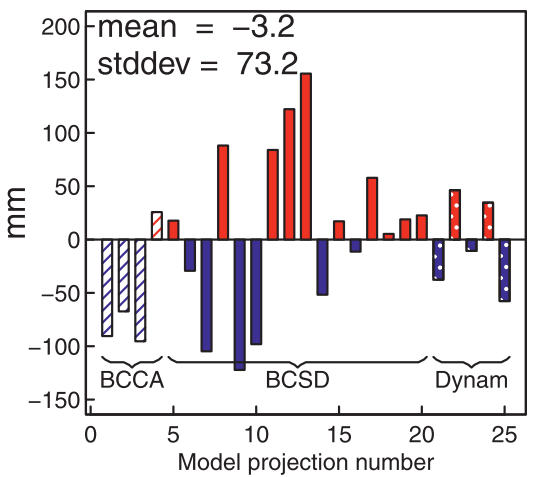

FIG. 8. Change in California's annual mean precipitation $(\mathrm{mm})$ due to the change in (a) the number of zero precipitation days, (b) precipitation intensity, and (c) the total annual mean change, equal to the sum of the components shown in (a) and (b). Model projection number is along the $x$ axis. Results using BCCA, BCSD, and dynamical downscaling are crosshatched, solid, and stippled, respectively.

downscaled data have been used in this analysis since those preserve the daily sequence of precipitation from the original global models. (In a sensitivity test we recomputed this figure using BCSD data and found little difference except in summer in the North American monsoon region where BCSD does not show the pronounced tendency toward wetter conditions.) Figure 2 shows that zero precipitation days increase over most of the domain, but Fig. 11 shows that this does not happen uniformly over the year. Virtually the entire state has
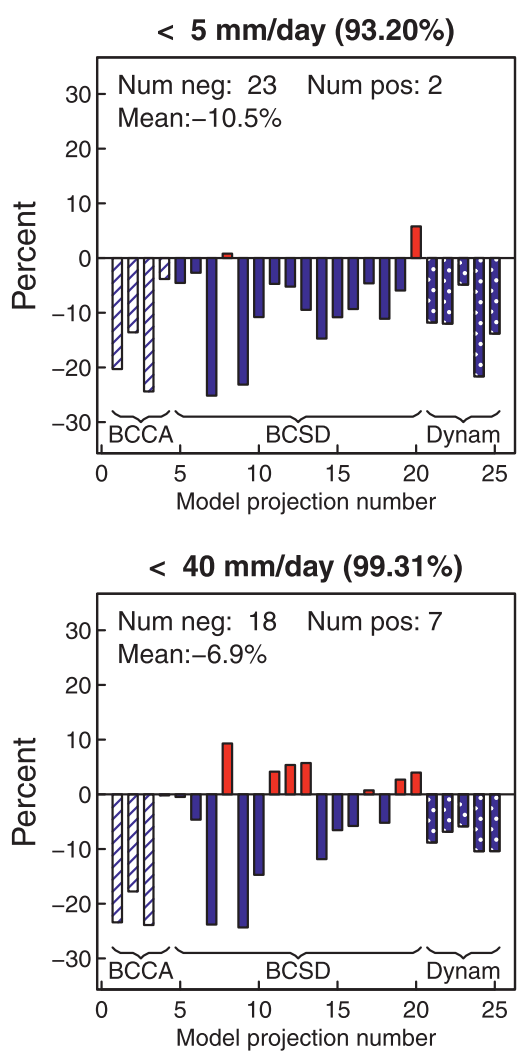
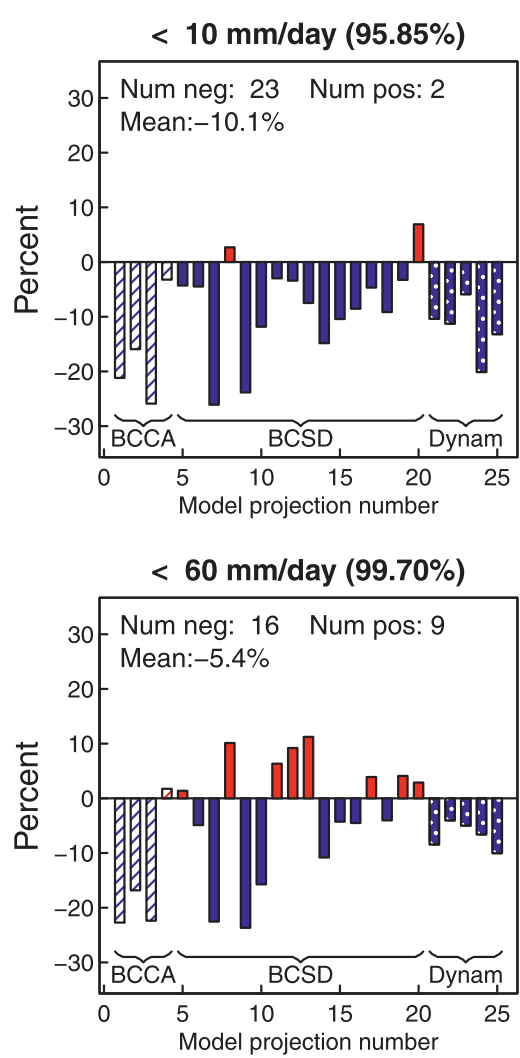
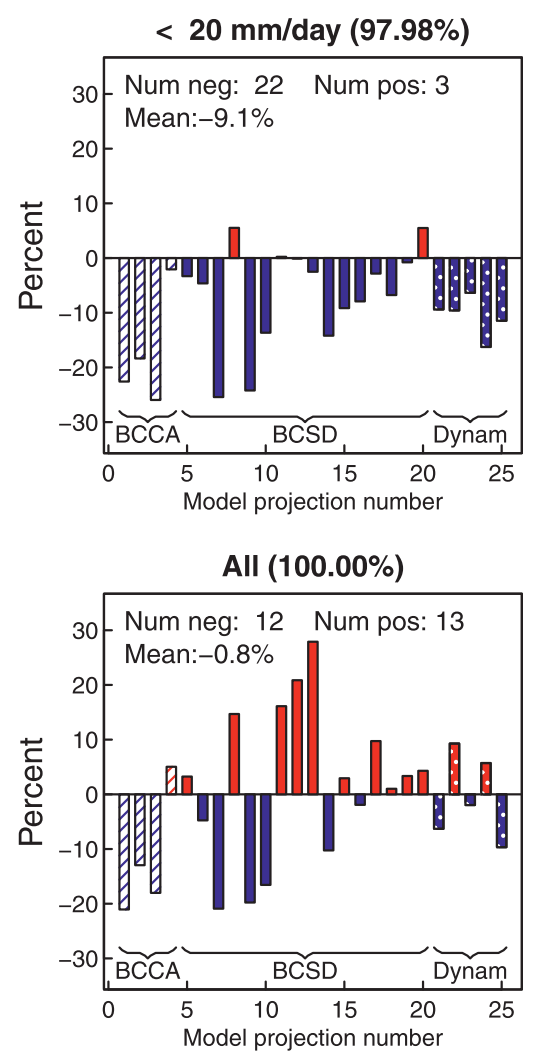

FIG. 9. Change in California's annual precipitation across model projections ( $x$ axis) when only days with less than the indicated precipitation rate $\left(\mathrm{mm} \mathrm{day}^{-1}\right)$ are included. The percentage in the title shows the fraction of grid-cell-days included for indicated cutoff. Results using BCCA, BCSD, and dynamical downscaling are crosshatched, solid, and stippled, respectively. 
a) $1-$ in- $\mathrm{N}$ rate, all days

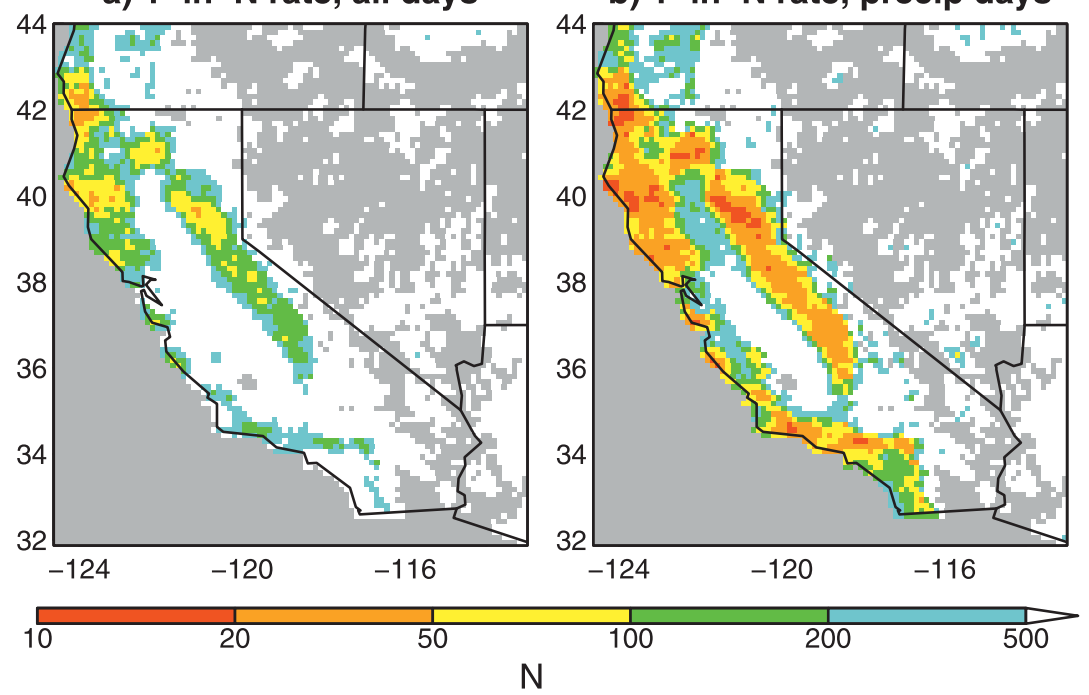

b) 1-in-N rate, precip days

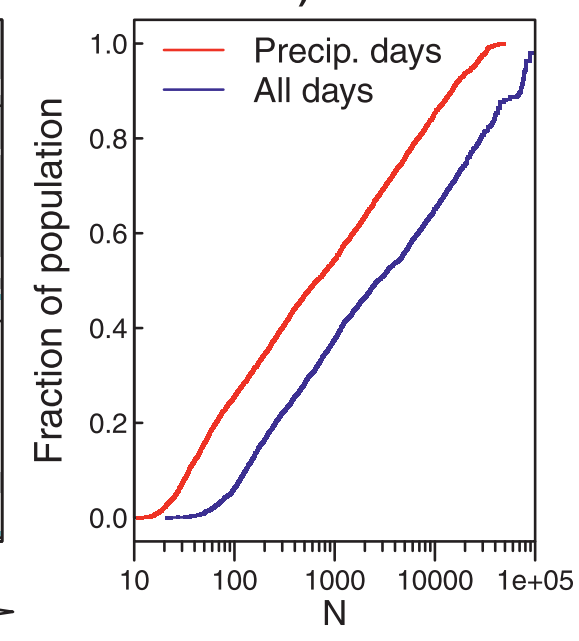

FIG. 10. Mean model occurrence rate (expressed as 1-in- $N$ days) of precipitation events with $>60 \mathrm{~mm} \mathrm{day}^{-1}$ (a) when considering all days and (b) when considering only days with precipitation: gray areas experienced no $60 \mathrm{~mm}^{\text {day }}{ }^{-1}$ events. (c) Empirical cumulative

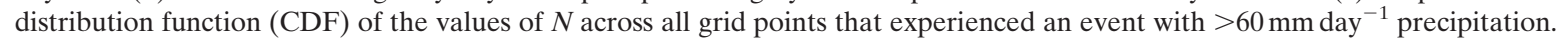

a statistically significant drop in spring precipitation (Fig. 11, top row), particularly in April. This is accompanied by a decrease in precipitating days (Fig. 11, middle row), although this decrease is not always statistically significant. This pattern is repeated, although more weakly, in the autumn: most regions show decreasing precipitation associated with fewer precipitating days.

Most of the regions, with the exception of the AnzaBorrego, show a tendency toward increasing 95th percentile precipitation during some or all of the cool season months (November-March, bottom row of Fig. 11). Winter average precipitation increases despite fewer precipitating days because precipitation events intensify.

Although this result is obtained with data pooled across the BCCA and dynamical downscaling techniques, the models do not all agree on this result. Of the four global models (CCSM3, GFDL 2.1, PCM1, and CNRM CM3), CCSM3 shows the strongest increase in winter precipitation intensity. GFDL 2.1 and PCM1 show weaker increases in intensity along the coast and decreases in the far northeast, while CNRM shows mild decreases in storm intensity (and winter decreases in precipitation of $8 \%-45 \%$, mostly due to fewer days with precipitation) throughout the state.

The Anza-Borrego (Fig. 11) and Inland Empire regions (not shown), which are affected by the North American monsoon, experience an increase in summer [JuneAugust (JJA)] precipitation that is associated with an increase in both precipitation frequency and intensity. Because of the spread of responses across the models, these changes are not statistically significant. CCSM3 and
GFDL show these increases strongly, while CNRM shows only a weak increase and PCM shows a slight decrease.

\section{f. Summary of changes in California precipitation frequency and intensity}

The overall effect of seasonal changes in daily precipitation intensity and frequency is shown in Fig. 13. Equivalent changes in seasonal precipitation $(\mathrm{cm})$ are calculated as in section $3 \mathrm{~d}$ (so that all values have the same units), and results averaged across all model projections. Each region's change in future precipitation is equal to the sum of changes due to the number of precipitating days and changes due to precipitation intensity.

In winter and spring almost all locations show an increase in daily precipitation intensity, except for the southern part of the state in winter. At the same time, almost all locations and seasons show a decrease in the number of precipitating days, except for summer when there are few precipitating days in California to begin with. The exception is the southeastern part of the state in summer, which shows more precipitating days. The way that the opposing tendencies of precipitation frequency and intensity combine yields a complex pattern of seasonal precipitation changes. In the northern part of the state in winter, the increase in storm intensity is stronger than the decrease in number of precipitating days, resulting in an overall mild (3\%-6\%) increase in seasonal precipitation. In spring [March-May (MAM)] a mild increase in daily precipitation intensity coupled with a strong decrease in number of precipitating days yields a significant tendency toward less precipitation 

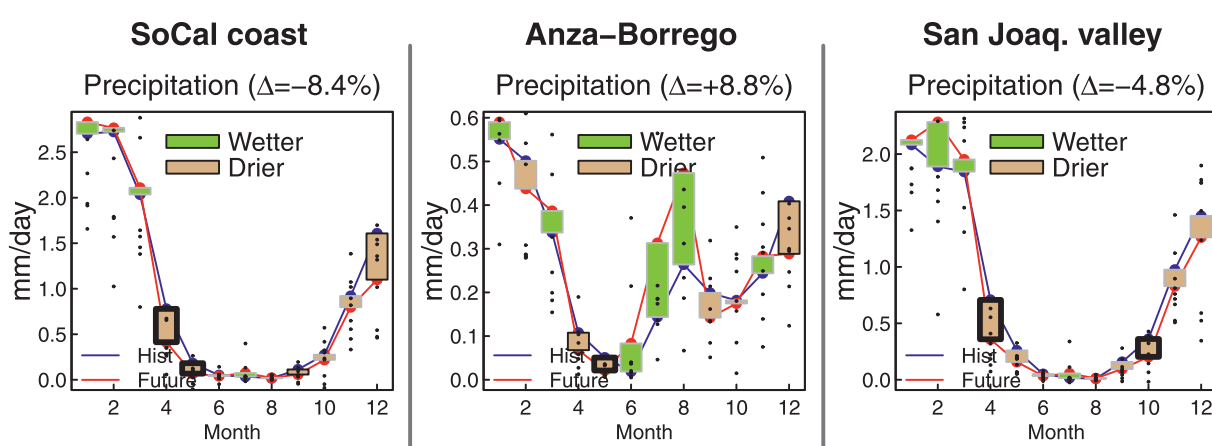

Rainy days $(\Delta=-13.2 \%)$

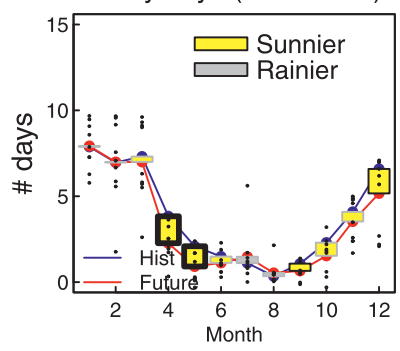

Percentiles

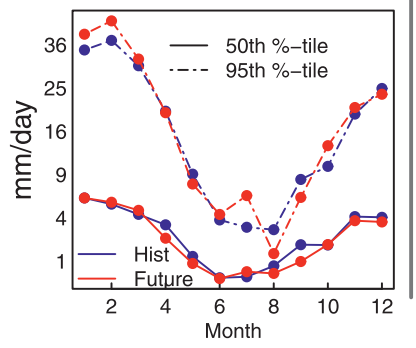

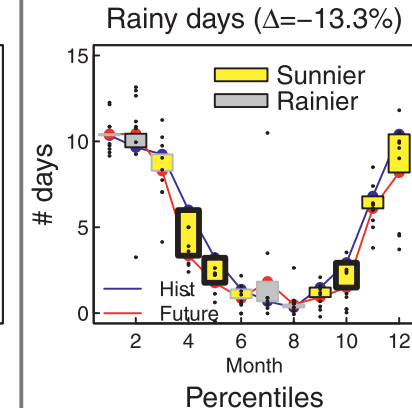
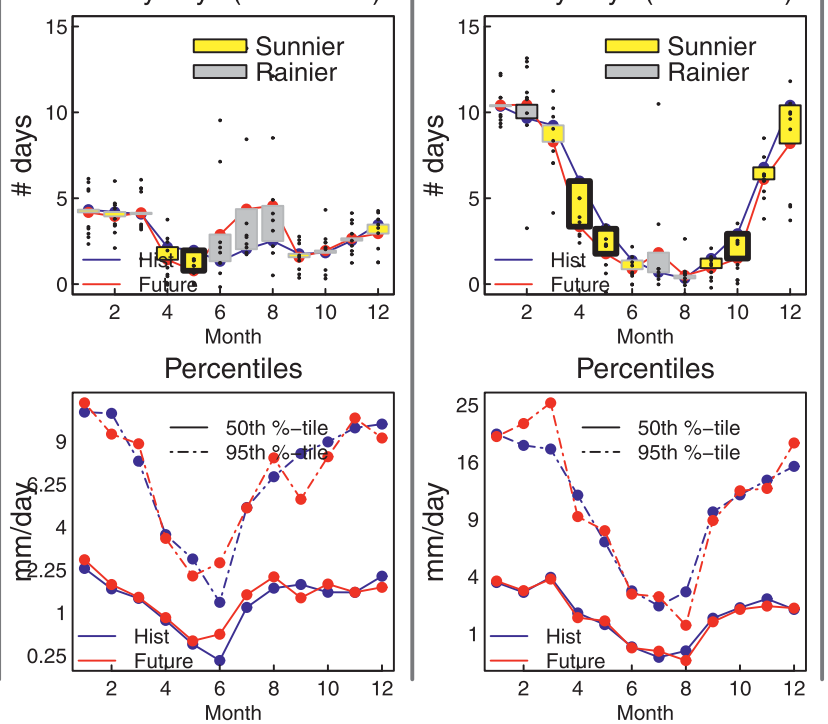

\section{Sierra Nevada}

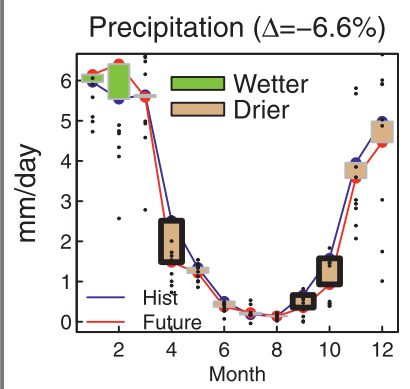

Rainy days $(\Delta=-13.6 \%)$
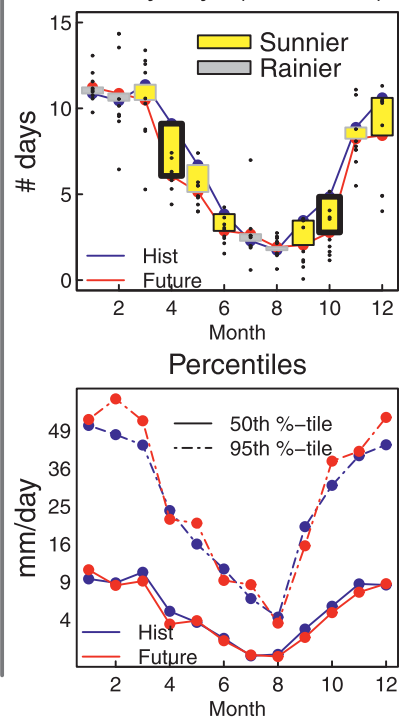

FIG. 11. Changes in precipitation intensity vs frequency over the annual cycle in four regions. (top row) Annual cycle of monthly precipitation $\left(\mathrm{mm} \mathrm{day}^{-1}\right)$ for the historical (blue) and future (red) eras. The change in yearly precipitation (\%) is in the title. At each month, a box is drawn between the historical and future values; the box is shaded green (brown) if the future value is wetter (drier). The box has a heavy outline if the difference is statistically significant at the $95 \%$ level, a normal outline if significant at the $90 \%$ level, and a light gray outline if not statistically significant. Black dots show individual model values. (middle row) Change in number of days with nonzero precipitation (rainy days); yellow boxes show a decrease in rainy days, while gray boxes show an increase. (bottom row) The 50th (solid line) and 95th (dashed line) percentiles of precipitation, calculated only on days when precipitation occurred, for the historical (blue) and future (red) eras. The $y$ axis uses a square root transformation to cover the wide range of values. Data from the dynamical and BCCA downscaling methods was used to make the figure.

(declines of $>10 \%$ ). This can also be seen in autumn [September-November (SON)], although the changes in storm intensity are small in this season. Finally, the southeastern part of California, on the edge of the region affected by the North American monsoon, shows both a mild increase in storm intensity and strong increase in number of precipitating days in summer (JJA), resulting in large $(>100 \%)$ increases in that season's precipitation.

\section{Summary and conclusions}

This work has evaluated future changes in daily precipitation intensity and frequency in California between the historical period 1985-94 and the 2060s. Our goal is to see how model disagreements in projected annual precipitation changes are expressed at the daily time scale.

We used data from 16 global climate models downscaled with a combination of statistical [bias correction with constructed analogs (BCCA) and bias correction with spatial disaggregation (BCSD)] and dynamical (WRF, RCM, and RegCM3) techniques, although not all downscaling techniques were applied to each global model. We analyzed 25 model projections in total, where a model projection is a unique combination of global model and downscaling technique. We used the 


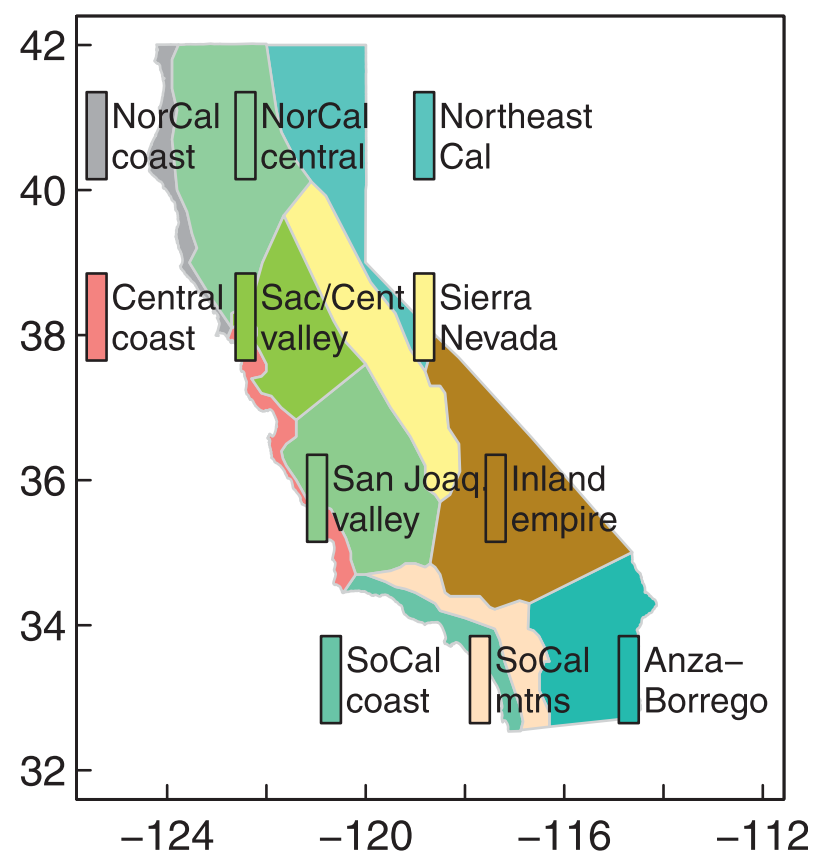

FIG. 12. California climate regions identified by Abatzoglou et al. (2009): subpanels in Fig. 13 are plotted in accordance with the locations shown here.

SRES A2 greenhouse gas and anthropogenic aerosols emissions scenario and equally weighted all model projections, since there is currently no basis in the published literature for weighting different downscaling techniques differently.

Our interest here is in water supply issues, so we focus on changes in total statewide precipitation rather than fractional changes relative to the local climatology. Twelve models project less annual precipitation, and 13 project more. The root of these differences is the way each model combines changes in precipitation frequency and daily precipitation intensity.

The model projections agree that substantial portions of California, particularly in the Sierra Nevada and northern coastal regions (which receive the majority of the state's precipitation) will have 6-14 fewer precipitating days per year. Over the northern half of the state, this represents a decline of about $8 \%-15 \%$. Twenty-one of the 25 projections agree on the sign of this decline.

Most of the model projections also agree that daily precipitation intensity will increase. Expressed as a fraction of the number of days that experience precipitation, the incidence of days with precipitation greater than $20 \mathrm{~mm} \mathrm{day}^{-1}$ increases by $25 \%-100 \%$ over almost the entire domain considered here. Expressed as an incidence rate over all days of the year (not just precipitating days), precipitation rates below $10 \mathrm{~mm} \mathrm{day}^{-1}$ decrease over nearly all of California, while most models project an increase in events of $60 \mathrm{~mm} \mathrm{day}^{-1}$ or more over the Sierra Nevada and northern coastal regions. This has implications for flood management (Das et al. 2011), particularly as winter precipitation transitions from rain to snow (e.g., Knowles et al. 2006) and the snow melts earlier in the year (e.g., Kim 2005; Hayhoe et al. 2004; Das et al. 2009). Heavier precipitation could also increase the fraction of precipitation that generates surface runoff, reducing groundwater recharge (Dettinger and Earman 2007).

Where the models disagree is whether the increase in precipitation intensity is sufficient to overcome the drying effects of fewer precipitating days. This disagreement arises largely from differences in the change in occurrence of events with precipitation $>60 \mathrm{~mm}_{\text {day }}{ }^{-1}$. The largest absolute (i.e., not fractional) changes in such heavy precipitation events occur preferentially in the Sierra Nevada and Northern California. The importance of changes in the incidence of heavy precipitation events is thus tied to the importance of locations where such events are relatively common. When such events are excluded, 1.8 times as many model projections show declining annual precipitation in California as increasing. When they are included, the model projections are about split between drier and wetter future conditions. The change in incidence of these heavy precipitation events depends on both the global model and downscaling technique.

Events of this magnitude are rare, constituting only about $9 \%$ of annual precipitation volume and 1 in every 10-50 precipitation events in the Sierra Nevada, northern coastal, and California coastal ranges, and are almost unknown elsewhere. This implies that efforts to narrow the range of future precipitation projections over California need to focus on model representation of the rarest, heaviest precipitation events, how such events might be enabled by the interaction of the regional meteorological setting with local topography, and the fidelity of the model atmospheric rivers (Zhu and Newell 1998). Atmospheric rivers play a key role in heavy precipitation over many parts of the world (e.g., Lavers et al. 2011; Neiman et al. 2011; Dettinger et al. 2011; Viale and Nuñez 2011; Krichak et al. 2012), so our results could apply to other regions as well.

Winter precipitation increases in the northern part of the state are driven by significant increases in daily precipitation intensity with only mild decreases in the number of precipitating days, while spring and autumn decreases in precipitation are driven by fewer precipitating days with only mild increases in precipitation intensity. The change in number of precipitating days may be related to the poleward movement of storm 


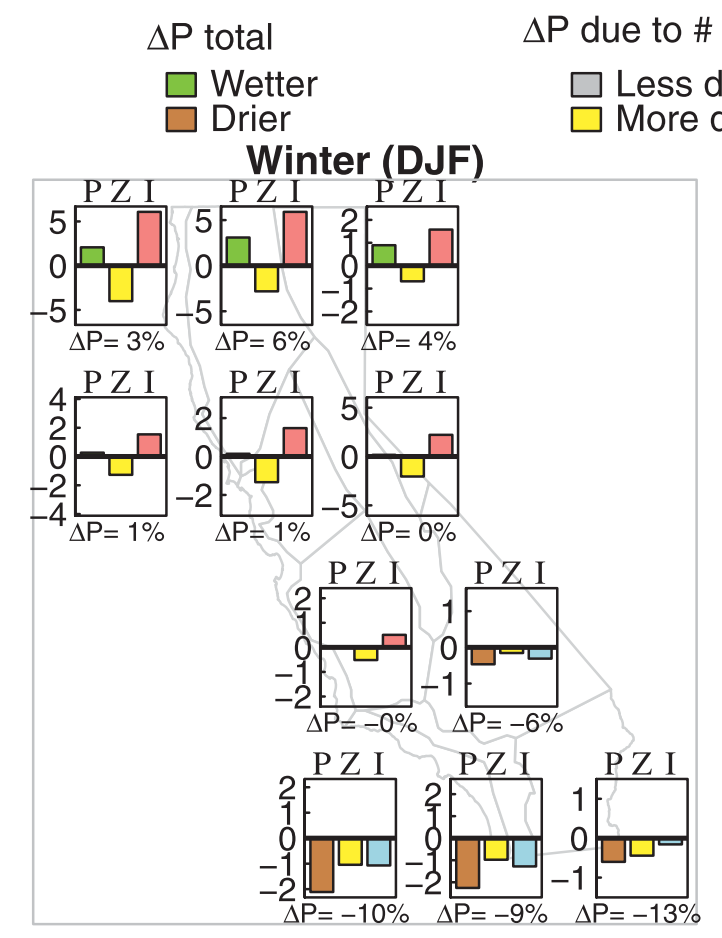

\section{zero days}

$\Delta \mathrm{P}$ due to storm intensity

Drier More dry days
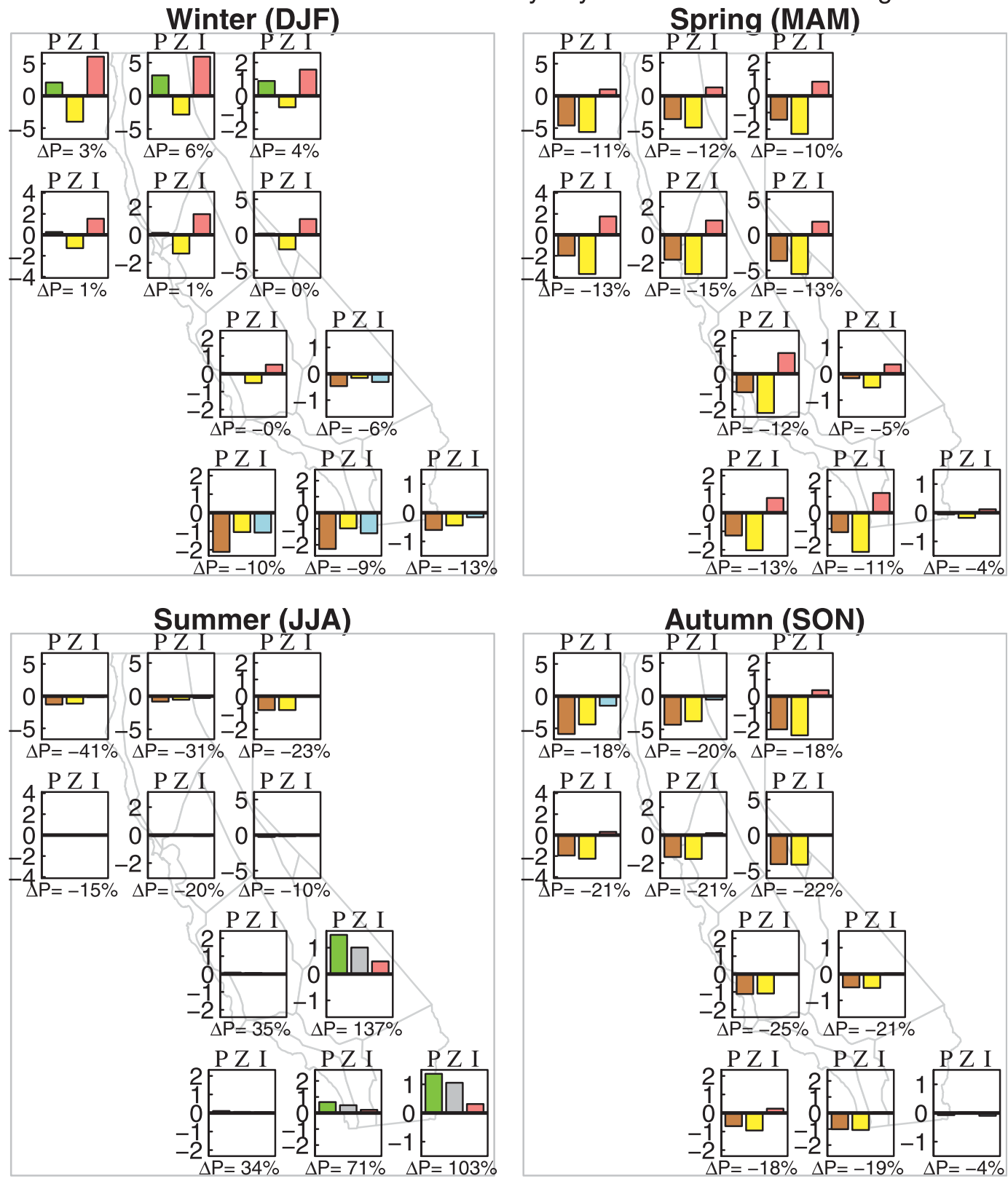

FIG. 13. Apportioning the seasonal precipitation change in each region to changes in storm frequency and intensity. In each set of three bars, the leftmost (marked "P") shows the change in precipitation during that season (cm). (For comparison, the change in seasonal precipitation is shown at the bottom of each subpanel, in percent.) This bar is colored green for positive (wetter future) changes, and brown for negative (drier future) changes. The middle bar ("Z") shows the change in seasonal precipitation $(\mathrm{cm})$ that arises due to the change in number of zero-precipitation days. Yellow indicates an increase in zero-precipitation days, and gray indicates a decrease. The rightmost bar ("I") shows the change in seasonal precipitation $(\mathrm{cm})$ that arises from the change in precipitation intensity. Red shows an increasing intensity; blue shows decreasing intensity. Note that the $y$ axis varies by region, but for each region is the same across all seasons. Subpanel locations are illustrated in Fig. 12. 
tracks, which is expected under human-induced climate change (e.g., Yin 2005; Salathé 2006; Ulbrich et al. 2008; Bender et al. 2012). In the southern part of the state, although many simulations exhibit moderate increases in winter precipitation intensity, these increases are offset and in several cases overwhelmed by decreases in the number of precipitating days. Overall, the water supply effects of the tendency of the snowpack to melt earlier in spring will be exacerbated by a decrease in spring precipitation. A similar finding for the headwaters of the Colorado River was obtained by Christensen and Lettenmaier (2007).

The dynamical downscaling techniques (WRF, RSM, and $\mathrm{RegCM} 3$ ) produced a nonlinear amplification of the global precipitation rate, with smaller rates of global precipitation amplified the most. If this leads the dynamical techniques to keep the soil more saturated than when BCCA downscaling is used, it could affect the runoff efficiency (fraction of precipitation that generates runoff) that is simulated when using different downscaling techniques. This could be usefully explored in future work.

Finally, we note that projected future changes in California's annual precipitation are generally small compared to either natural interannual climate variability or the spread between different model projections (e.g., Dettinger 2005; Pierce et al. 2012). These results show that divergent model estimates of future annual precipitation may be composed of individual seasonal changes in daily precipitation intensity and frequency that have a specific geographical setting and are much more consistent across models. Future attempts to examine whether human-induced climate change is measurably affecting California's precipitation might find identifiable changes in these other aspects of the precipitation field long before the net annual change becomes evident.

Acknowledgments. This work was funded by the Public Interest Energy Research (PIER) program of the California Energy Commission (CEC), Grant 500-07042 to the Scripps Institution of Oceanography at UC San Diego: Development of probabilistic climate projections for California. DWP also received partial support from the Department of Energy, award DE-SC0002000, to examine future changes in climate model precipitation events, and the International ad-hoc Detection and Attribution (IDAG) project in furtherance of work to examine how daily timescale precipitation events change to accomplish low frequency global climate changes. Partial salary support for TD from the CALFED Bay-Delta Program-funded postdoctoral fellowship grant, and for DRC and MT from the NOAA through the California Nevada Applications Program RISA activity, is also acknowledged. We thank the global modeling groups that contributed data to the CMIP3 archive; without their efforts and generosity in sharing the data, this work would have been impossible. The manuscript was improved by the comments of two anonymous reviewers, whom we thank for their contributions.

\section{REFERENCES}

Abatzoglou, J. T., K. T. Redmond, and L. M. Edwards, 2009: Classification of regional climate variability in the state of California. J. Appl. Meteor. Climatol., 48, 1527-1541.

Anderson, J., F. Chung, M. Anderson, L. Brekke, D. Easton, M. Ejeta, R. Peterson, and R. Snyder, 2008: Progress on incorporating climate change into management of California's water resources. Climate Change, 87 (Suppl. 1), S91-S108, doi:10.1007/s10584-007-9353-1.

Bender, F. A. M., V. Ramanathan, and G. Tselioudis, 2012: Changes in extratropical storm track cloudiness 1983-2008: Observational support for a poleward shift. Climate Dyn., 38, 2037-2053.

Caldwell, P., H. N. S. Chin, D. C. Bader, and G. Bala, 2009: Evaluation of a WRF dynamical downscaling simulation over California. Climatic Change, 95, 499-521.

Chen, C.-T., and T. Knutson, 2008: On the verification and comparison of extreme rainfall indices from climate models. J. Climate, 21, 1605-1621.

Christensen, N. S., and D. P. Lettenmaier, 2007: A multimodel ensemble approach to assessment of climate change impacts on the hydrology and water resources of the Colorado River basin. Hydrol. Earth Syst. Sci., 11, 1417-1434.

Dai, A., 2006: Precipitation characteristics in eighteen coupled climate models. J. Climate, 19, 4605-4630.

Das, T., and Coauthors, 2009: Structure and origins of trend in hydrological measures over the western United States. $J$. Hydrometeor., 10, 871-892.

, M. D. Dettinger, D. R. Cayan, and H. G. Hidalgo, 2011: Potential increase in floods in California's Sierra Nevada under future climate projections. Climatic Change, 109 (Suppl. 1), S71-S94.

Dettinger, M. D., 2005: From climate-change spaghetti to climatechange distributions for 21st century California. San Francisco Estuary and Watershed Science, No. 3 (1), 14 pp. [Available online at http://repositories.cdlib.org/jmie/sfews/vol3/iss1/art4.] 2011: Climate change, atmospheric rivers and floods in California-A multimodel analysis of storm frequency and magnitude changes. J. Amer. Water Resour. Assoc., 47, 514-523.

, and S. Earman, 2007: Western ground water and climate change-Pivotal to supply sustainability or vulnerable in its own right? Ground Water News and Views, No. 4, National Ground Water Association, Westerville, OH, 4-5.

— , F. M. Ralph, T. Das, P. J. Neiman, and D. R. Cayan, 2011: Atmospheric rivers, floods and the water resources of California. Water, 3, 445-478, doi:10.3390/w3020445.

Duffy, P. B., and Coauthors, 2006: Simulations of present and future climates in the western United States with four nested regional climate models. J. Climate, 19, 873-895.

Franco, G., D. Cayan, S. C. Moser, M. H. Hanemann, and M. A. Jones, 2011: Second California Assessment: Integrated climate change impacts assessment of natural and managed systems. Climatic Change, 109 (Suppl. 1), 1-19, doi:10.1007/ s10584-011-0318-z. 
Hamlet, A. F., and D. P. Lettenmaier, 2005: Production of temporally consistent gridded precipitation and temperature fields for the continental United States. J. Hydrometeor., 6, 330-336.

Hayhoe, K., and Coauthors, 2004: Emissions pathways, climate change, and impacts on California. Proc. Natl. Acad. Sci. USA, 101, 12 422-12427.

Hidalgo, H. G., M. D. Dettinger, and D. R. Cayan, 2008: Downscaling with constructed analogues: Daily precipitation and temperature fields over the United States. California Energy Commission Tech. Rep. CEC-500-2007-123, 48 pp.

Kanamitsu, M., H. Kanamaru, Y. Cui, and H. Juang, 2005: Parallel implementation of the regional spectral atmospheric model. California Energy Commission Tech. Rep. CEC-500-2005014, $17 \mathrm{pp}$.

Kim, J., 2005: A projection of the effects of the climate change induced by increased $\mathrm{CO}_{2}$ on extreme hydrologic events in the western U.S. Climatic Change, 68, 153-168.

Knowles, N., M. D. Dettinger, and D. R. Cayan, 2006: Trends in snowfall and rainfall in the western United States. J. Climate, 19, 4545-4559.

Krichak, S. O., J. S. Breitgand, and S. B. Feldstein, 2012: A conceptual model for the identification of active Red Sea trough synoptic events over the southeastern Mediterranean. J. Appl. Meteor. Climatol., 51, 962-971.

Lavers, D. A., R. P. Allan, E. F. Wood, G. Villarini, D. J. Brayshaw, and A. J. Wade, 2011: Winter floods in Britain are connected to atmospheric rivers. Geophys. Res. Lett., 38, L23803, doi:10.1029/2011GL049783.

Leung, L. R., Y. Qian, X. D. Bian, W. M. Washington, J. G. Han, and J. O. Roads, 2004: Mid-century ensemble regional climate change scenarios for the western United States. Climatic Change, 62, 75-113.

Liang, X.-Z., K. E. Kunkel, G. A. Meehl, R. G. Jones, and J. X. L. Wang, 2008: Regional climate models downscaling analysis of general circulation models present climate biases propagation into future change projections. Geophys. Res. Lett., 35, L08709, doi:10.1029/2007GL032849.

Maurer, E. P., 2007: Uncertainty in hydrologic impacts of climate change in the Sierra Nevada, California, under two emissions scenarios. Climatic Change, 82, 309-325.

— scale climate data: An intercomparison of two statistical downscaling methods. Hydrol. Earth Syst. Sci., 12, 551-563.

,-- , T. Das, M. D. Dettinger, and D. R. Cayan, 2010: The utility of daily large-scale climate data in the assessment of climate change impacts on daily streamflow in California. Hydrol. Earth Syst. Sci., 14, 1125-1138, doi:10.5194/ hess-14-1125-2010.

Meehl, G. A., J. M. Arblaster, and C. Tebaldi, 2005: Understanding future patterns of increased precipitation intensity in climate models. Geophys. Res. Lett., 32, L18719, doi:10.1029/ 2005GL023680.

Miller, N. L., and Coauthors, 2009: An analysis of simulated California climate using multiple dynamical and statistical techniques. California Energy Commission Rep. CEC-5002009-017-F, 47 pp.

Muller, C. J., P. A. O'Gorman, and L. E. Back, 2011: Intensification of precipitation extremes with warming in a cloud-resolving model. J. Climate, 24, 2784-2800.

Nakicenovic, N., and R. Swart, Eds., 2000: Special Report on Emissions Scenarios. Cambridge University Press, 599 pp.
Neiman, P. J., L. J. Schick, F. M. Ralph, M. Hughes, and G. A. Wick, 2011: Flooding in western Washington: The connection to atmospheric rivers. J. Hydrometeor., 12, 1337-1358.

O'Gorman, P. A., and T. Schneider, 2009: The physical basis for increases in precipitation extremes in simulations of 21st-century climate change. Proc. Natl. Acad. Sci. USA, 106, 14773-14777.

Pal, J. S., F. Giorgi, X. Q. Bi, N. Elguindi, and Coauthors, 2007 Regional climate modeling for the developing world: The ICTP RegCM3 and RegCNET. Bull. Amer. Meteor. Soc., 88, 1395-1409.

Panofsky, H. A., and G. W. Brier, 1968: Some Applications of Statistics to Meteorology. The Pennsylvania State University, $224 \mathrm{pp}$.

Pierce, D. W., and Coauthors, 2012: Probabilistic estimates of future changes in California temperature and precipitation using statistical and dynamical downscaling. Climate Dyn., 40, 839856, doi:10.1007/s00382-012-1337-9.

Ralph, F. M., and M. D. Dettinger, 2011: Storms, floods and the science of atmospheric rivers. Eos, Trans. Amer. Geophys. Union, 92, 265-266.

— and - 2012: Historical and national perspectives on extreme West Coast precipitation associated with atmospheric rivers during December 2010. Bull. Amer. Meteor. Soc., 93, 783-790.

Salathé, E. P., Jr., 2006: Influences of a shift in North Pacific storm tracks on western North American precipitation under global warming. Geophys. Res. Lett., 33, L19820, doi:10.1029/ 2006 GL026882.

Skamarock, W. C., and Coauthors, 2008: A description of the Advanced Research WRF version 3. NCAR Tech. Note NCAR/TN-475+STR, 125 pp.

Solomon, S., D. Qin, M. Manning, Z. Chen, M. Marquis, K. Averyt, M. M. B. Tignor, and H. L. Miller Jr., Eds., 2007: Climate Change 2007: The Physical Science Basis. Cambridge University Press, 996 pp.

Stephens, G. L., and Y. Hu, 2010: Are climate-related changes to the character of global-mean precipitation predictable? Environ. Res. Lett., 5, 025209, doi:10.1088/1748-9326/5/2/025209.

Sun, Y., S. Solomon, A. Dai, and R. W. Portmann, 2006: How often does it rain? J. Climate, 19, 916-934.

Ulbrich, U., J. G. Pinto, H. Kupfer, G. C. Leckebusch, T. Spangehl, and M. Reyers, 2008: Changing Northern Hemisphere storm tracks in an ensemble of IPCC climate change simulations. J. Climate, 21, 1669-1679.

Viale, M., and M. N. Nuñez, 2011: Climatology of winter orographic precipitation over the subtropical central Andes and associated synoptic and regional characteristics. J. Hydrometeor., 12, 481-507.

Wehner, M. F., R. L. Smith, G. Bala, and P. Duffy, 2010: The effect of horizontal resolution on simulation of very extreme U.S. precipitation events in a global atmosphere model. Climate Dyn., 34, 241-247.

Wood, A. W., E. P. Maurer, A. Kumar, and D. P. Lettenmaier, 2002: Long-range experimental hydrologic forecasting for the eastern United States. J. Geophys. Res., 107, 4429, doi:10.1029/ 2001JD000659.

— , L. R. Leung, V. Sridhar, and D. P. Lettenmaier, 2004: Hydrologic implications of dynamical and statistical approaches to downscaling climate model outputs. Climatic Change, 62, 189-216.

Yin, J., 2005: A consistent poleward shift of the storm tracks in simulations of the 21 st century climate. Geophys. Res. Lett. 32, L18701, doi:10.1029/2005GL023684.

Zhu, Y., and R. E. Newell, 1998: A proposed algorithm for moisture fluxes from atmospheric rivers. Mon. Wea. Rev., 126, 725-735. 